\title{
IDŐJÁRÁS
}

Quarterly Journal of the Hungarian Meteorological Service

Vol. 125, No. 4, October-December, 2021, pp. 647-673

\section{ALADIN-Climate at the Hungarian Meteorological Service: from the beginnings to the present day's results}

\author{
Beatrix Bán*,1, Gabriella Szépszó ${ }^{1}$, Gabriella Allaga-Zsebeházi ${ }^{1}$, \\ and Samuel Somot ${ }^{2}$ \\ ${ }^{1}$ Hungarian Meteorological Service \\ Kitaibel Pál u. 1; H-1024 Budapest, Hungary \\ ${ }^{2}$ CNRM (Centre National de Recherches Météorologiques) \\ Université de Toulouse, Météo-France, CNRS, Toulouse, France \\ 42 avenue Coriolis, 31057 Toulouse, France \\ *Corresponding author e-mail: ban.b@met.hu
}

(Manuscript received in final form October 2, 2021)

\begin{abstract}
This study is focusing on the past and, in particular, the present of the ALADIN-Climate model used at the Hungarian Meteorological Service. The currently applied model version is 5.2 (HMS-ALADIN52). In the recent experiments, the CNRMCM5 global model outputs were downscaled in two steps to $10 \mathrm{~km}$ horizontal resolution over Central and Southeast Europe using RCP4.5 and RCP8.5 scenarios. Temperature and precipitation projections are analyzed for 2021-2050 and 2071-2100 with respect to the reference period of 1971-2000 with focus on Hungary. The results are evaluated in comparison to 26 simulations selected from the $12 \mathrm{~km}$ horizontal resolution EuroCORDEX projection ensemble (including two additional versions of ALADIN-Climate: CNRM-ALADIN53 and CNRM-ALADIN63) to get more information about the projection uncertainties over Hungary and to assess the representativeness of HMS-ALADIN52.

The HMS-ALADIN52 simulations project a clear warming trend in Central and Southeast Europe, which is more remarkable in case of greater radiative forcing change (RCP8.5). From the 2040s, the Euro-CORDEX simulations start to diverge using different scenarios. The total range of the annual change over Hungary is $1.3-3.3^{\circ} \mathrm{C}$ with RCP4.5 and $3.2-5.7^{\circ} \mathrm{C}$ with RCP 8.5 by the end of the 21 st century. HMS-ALADIN52 results are approximately near to the median: $2.9{ }^{\circ} \mathrm{C}$ with RCP4.5 and $4{ }^{\circ} \mathrm{C}$ with RCP8.5. CNRMALADIN53 shows generally similar results to HMS-ALADIN52, but simulations with CNRM-ALADIN63 indicate higher changes compared to both. In terms of seasonal mean precipitation change, the HMS-ALADIN52 simulations assume an increase between 9\% and 33\% (less in spring, more in autumn) over Hungary in both periods and with both scenarios. Most of the selected Euro-CORDEX simulations show a precipitation increase, apart from summer, when growth and reduction can be equally expected in 2021-2050, and the drying tendency continues towards the end of the century. Increase projected by HMSALADIN52 is mostly confirmed by CNRM-ALADIN53, while CNRM-ALADIN63
\end{abstract}


predicts precipitation decrease in summer. Precipitation results do not show a significantly striking difference between the scenarios, likely due to the fact that internal variability and model uncertainty are more relevant sources of uncertainty in precipitation projections over our region.

Key-words: regional climate modeling, Hungary, projection, temperature, precipitation, ALADIN, Euro-CORDEX, ensemble

\section{Introduction}

During the early 2000s, it was decided at the Hungarian Meteorological Service (HMS) to start working in the field of regional climate modeling in order to provide a firm basis for climate change adaptation in Hungary. A pragmatic approach was taken in the search of regional climate models (RCM) to be used, and the ALADIN model was selected in addition to the REMO model (Szépszó and Horányi, 2008). The ALADIN limited area numerical weather prediction (NWP) model (Termonia et al., 2018) has been developed through an international cooperation, and for now the ALADIN model family is the most widely used limited area model in Europe (it has been used also in operational practice of HMS since the 1990s). Its two specific versions were considered in these early days. The first one was basically the short-range NWP version of the model (Farda et al., 2010), which included only minor changes for the climate version. The second one was a dedicated model version called ALADIN-Climate (Radu et al., 2008), which was built by merging the physical parameterization package of the ARPEGE-Climat global climate model (Déqué et al., 1994) and the dynamics of the ALADIN model. That version was more tailored for climate use and was adapted at the Hungarian Meteorological Service. This model has been used for various climate experiments including some shorter (few years) experimentation to establish the most appropriate model version, domain, horizontal resolution, and the spin-up time.

At HMS, the first longer experiments were performed by reanalysis lateral boundary conditions (LBCs) and then using global climate model (ARPEGEClimat) LBCs in order to understand the behavior of the model for the past. While the ERA-40 (Uppala et al., 2005) driven experiment was achieved at $25 \mathrm{~km}$ resolution over Central Europe, the ARPEGE-driven simulation covered only the Carpathian Basin with $10 \mathrm{~km}$ resolution. The validation demonstrated that the domain size affects the results: using the smaller integration area led to an overestimation in summer precipitation and an underestimation in temperature (Csima and Horányi, 2008).

The first climate change run with ALADIN-Climate 4.5 was carried out in the framework of the CECILIA EU FP6 project (Halenka, 2007) between 2006 and 2009. The experiment was accomplished for two future time slices (2021-2050 and 2071-2100) using the medium A1B SRES scenario (Nakicenovic et al., 2000) to provide RCM outputs for assessment of the climate change effects on extreme 
events, air pollution, agriculture, water- and energy management in Central and Eastern Europe. The ALADIN-Climate results showed significant temperature increase and strong summer and lower winter reduction in precipitation over the Carpathian Basin for the 21st century (however, the latter outcome was neither confirmed by the results of the REMO model applied also at the Hungarian Meteorological Service nor by the available results of other European RCMs; Krüzselyi et al., 2011; Belda et al., 2015; Christensen et al., 2007a).

In the early $2010 \mathrm{~s}$, outputs of four locally run regional climate models were available in Hungary (Krüzselyi et al., 2011). A National Adaptation Geoinformation System (NAGiS; Kajner et al., 2017) was created in 2013 to support climate adaptation and related decision making in Hungary with coordinated impact studies. Their model basis for the future climate projections are the ALADIN-Climate and RegCM (Torma et al., 2008) RCMs. The climate information available in NAGiS is utilized in vulnerability assessments in many sectors, e.g., tourism, hydrology, human health (Kovács et al., 2015; BedeFazekas et al., 2017; Homolya et al., 2017; Lepesi et al., 2017).

Parallel to the vulnerability assessments, HMS aimed to update the climate simulation base of NAGIS in a side-project of NAGiS and later in the EU-funded KlimAdat project from 2016. A new version (5.2) of the ALADIN-Climate model was applied over a domain covering Central and Eastern Europe with $10 \mathrm{~km}$ resolution. For the evaluation and control runs, ERA-Interim reanalysis (Dee et $a l ., 2011)$ and the 5th version of ARPEGE-Climat, which is the atmospheric part of the CNRM-CM5 general global circulation model (Voldoire et al., 2013) provided the lateral boundary conditions, respectively. The magnitude of the temperature underestimation and the summer precipitation overestimation over Hungary reduced in the new experiments (Illy et al., 2015). New, transient climate change simulations are also accomplished using the RCP (Representative Concentration Pathways) anthropogenic scenario family defined for the Fifth Assessment Report of the IPCC (Moss et al., 2010).

In order to properly describe future climate change, uncertainties of climate projections need to be taken into account. Therefore, other model results have been considered besides the ALADIN-Climate simulations. The World Climate Research Program established the CORDEX (Coordinated Regional Downscaling Experiment, http://cordex.org; Giorgi et al., 2009) collaboration which provides an internationally coordinated framework to improve regional climate scenarios over every continent. Simulations are performed mostly at $50 \mathrm{~km}$ (EUR-44) resolution over the predefined continent-sized domains until the end of the $21 \mathrm{st}$ century, but in the framework of Euro-CORDEX initiative (http://www.eurocordex.net/; Jacob et al., 2014), experiments over Europe are performed also at a finer $12.5 \mathrm{~km}$ (EUR-11) resolution. The regional simulations downscale the CMIP5 global climate projections (Taylor et al., 2012) and take into account the RCP scenarios. 
The aim of this study is to present the projection results of the ALADINClimate regional climate model for Hungary, and to examine how these simulations relate to a Euro-CORDEX EUR-11 (Jacob et al., 2014) model ensemble. The latter question is important for practical reasons as well, since future climate change uncertainties can be best quantified with multi-model and multi-scenario ensembles, and in Hungary, the computing capacities are limited to run several simulations with different models. After the historical overview, in Section 2, first the current model version adapted at HMS and the selected EuroCORDEX ensemble are introduced, emphasizing the included ALADIN-Climate 5.3 and 6.3 RCM versions. Then, experiments achieved with ALADIN-Climate 5.2, the analyzed Euro-CORDEX simulations, and the evaluation methods are also presented. Section 3 is dedicated to assess the temperature and precipitation projection results of the latest $10 \mathrm{~km}$ simulations of ALADIN-Climate 5.2, prepared with two different scenarios and the comparison to the Euro-CORDEX ensemble. Finally, a summary is given in Section 4.

\section{Data and methodology}

\subsection{The studied ALADIN-Climate model versions}

ALADIN-Climate is a hydrostatic, spectral regional climate model, which 5.2 version (Colin et al., 2010; hereinafter HMS-ALADIN52) is currently applied at the Hungarian Meteorological Service. The dynamic core of this model version is based on the cycle 32 of the ALADIN numerical weather prediction model, while the physical parameterization package is originated from the 5th version of the ARPEGE-Climat global climate model. The horizontal grid type of the model is a Lambert conformal conic projection, while the model applies the hybrid (terrain-following near the surface, that continuously turns into pressure levels at higher altitudes) coordinate system. The prognostic variables are the horizontal components of wind speed, temperature, specific humidity on model levels, and the surface air pressure. A combination of semi-implicit and semi-Lagrangian schemes are applied to determine the temporal evolution of the prognostic variables, which allows the use of a longer integration time step. The lateral boundary conditions and the RCM fields are smoothed to each other in the relaxation zone (an 8-gridpoint bound around the RCM central domain; Davies, 1976).

The main physical parameterization schemes are the followings: longwave radiation is described by the RRTM scheme (Rapid Radiation Transfer Model; Mlawer et al., 1997) which takes into account the emission and absorption of longwave radiation and the effects of particular atmospheric gases and aerosols. The calculation of the shortwave radiation flux is done by the Fouquart and Bonnel (1980) scheme, which describes the reflection, scattering, and absorption of shortwave radiation, and also considers the absorption of each atmospheric 
trace gas and the modifying effect of cloud cover. Ricard and Royer's (1993) scheme is used for large scale cloudiness and Smith's scheme (1990) for large scale precipitation. The parameterization of convection is based on the scheme of Bougeault (1985). The land surface processes are described by the SURFEX land surface model (Masson et al., 2013) that applies different schemes over the natural land, inland water, sea, and town surfaces. In the present model configuration, the ISBA scheme (Interaction of Soil Biosphere Atmosphere; Noilhan and Planton, 1989) was applied over the natural land surfaces, urban surfaces were described as rocks, while over water surfaces the simple Charnock formula (Charnock, 1955) gives surface fluxes using prescribed surface temperature.

The impact of human activity is considered through the annual global mean evolution of the atmospheric concentrations of greenhouse gases $\left(\mathrm{CO}_{2}, \mathrm{CH}_{4}, \mathrm{~N}_{2} \mathrm{O}\right.$, CFC-11, CFC-12) and certain types of aerosols (black coal, organic aerosol, sulphate, sea salt, dust). Aerosols are described in monthly distributions for 10year periods in the historical period (Tegen et al., 1997), as well as in the scenario periods (Szopa et al., 2013).

ALADIN-Climate version 5.3 and 6.3 (also known as CNRM-ALADIN53; Colin et al., 2010 and CNRM-ALADIN63; Nabat et al., 2020) have been developed and applied for regional climate model simulations, e.g., in the EuroCORDEX framework by the Centre National de Recherches Météorologiques (CNRM), the research department of the French national weather service, MétéoFrance. CNRM-ALADIN53 is very close to the version 5.2 used at HMS and it was described above. The main difference is that CNRM-ALADIN53 does not use the SURFEX land surface model (but a similar version of ISBA for the natural surfaces). For completeness, note that the HMS-ALADIN52 version is relatively different from the ALADIN5 version used by CNRM in Med-CORDEX (Tramblay et al., 2013) and the MENA domain (Driouech et al., 2020), but is identical to the CNRM version used for CORDEX North America (Lucas-Picher et al., 2013).

On the contrary, CNRM-ALADIN63 is a very different version as more than 10 years of model development occurred between version 5 and version 6 of ALADIN. It is described in detail in Nabat et al. (2020) and the main differences between ALADIN5 and ALADIN6 are summarized in Ivusic et al. (2021, in rev.) CNRM-ALADIN53 and CNRM-ALADIN63 are part of the latest $12 \mathrm{~km}$ resolution Euro-CORDEX ensemble that has been assessed in Vautard et al. (2021) and Coppola et al. (2021).

\subsection{Experiments with HMS-ALADIN52}

Two simulations (Table 1) have been created for the future with ALADIN52 at the Hungarian Meteorological Service using the high-emission RCP8.5 and the intermediate emission RCP4.5 scenarios for greenhouse gases. The numbers in the scenario names indicate the expected change in radiative forcing (i.e., 
$8.5 \mathrm{~W} / \mathrm{m}^{2}$ and $4.5 \mathrm{~W} / \mathrm{m}^{2}$, respectively) by the end of the $21 \mathrm{st}$ century compared to the pre-industrial level. The associated aerosol distributions were determined from simulations with global air chemistry (INCA Chemistry model) and general circulation models (Szopa et al., 2013). The lateral boundary conditions have 1.4 degree (approximately $150 \mathrm{~km}$ on our latitudes) horizontal resolution and are provided by the CNRM-CM5 general global circulation model, that was dynamically downscaled to $50 \mathrm{~km}$ resolution with HMS-ALADIN52 to the EuroCORDEX domain. CNRM-CM5 includes the ARPEGE-Climat atmospheric model, the NEMO ocean model (Madec, 2008), the ISBA land surface scheme (Noilhan and Planton, 1989), and the GELATO sea ice model (Salas y Melia, 2002) coupled through the OASIS system (Valcke, 2006). The $50 \mathrm{~km}$ horizontal resolution fields are then downscaled to $10 \mathrm{~km}(0.09$ degree $)$ on a domain covering Central and Southeast Europe (Fig. 1, left). An error has been recently reported concerning the CNRM-CM5 GCM files that were used as atmospheric lateral boundary conditions for the ALADIN52 and ALADIN53 runs (www.umrcnrm.fr/cmip5/spip.php?article24\&lang=en), but this likely has no significant effect on the long-term climate change signal. Sea surface temperature (SST) is derived from the CNRM-CM5 model, which is used directly by the $50 \mathrm{~km}$ resolution HMS-ALADIN52 simulations. The SST forcing of the $10 \mathrm{~km}$ HMSALADIN52 is more complex, which takes into account the $50 \mathrm{~km}$ HMSALADIN52 results and the use of SURFEX (sea-surface ratio). In our HMSALADIN52 experiments, there is no ocean/sea coupling.

Table 1. Features of the HMS-ALADIN52 simulations

\begin{tabular}{lc}
\hline \hline & HMS-ALADIN52 \\
\hline \hline Lateral boundary conditions & $\begin{array}{c}50 \text { km resolution HMS-ALADIN52 } \\
\text { driven by CNRM-CM5 }\end{array}$ \\
Projection & Lambert \\
Horizontal resolution & $10 \mathrm{~km}$ \\
Number of vertical levels & 31 \\
Time interval & $1950-2100$ \\
\hline
\end{tabular}



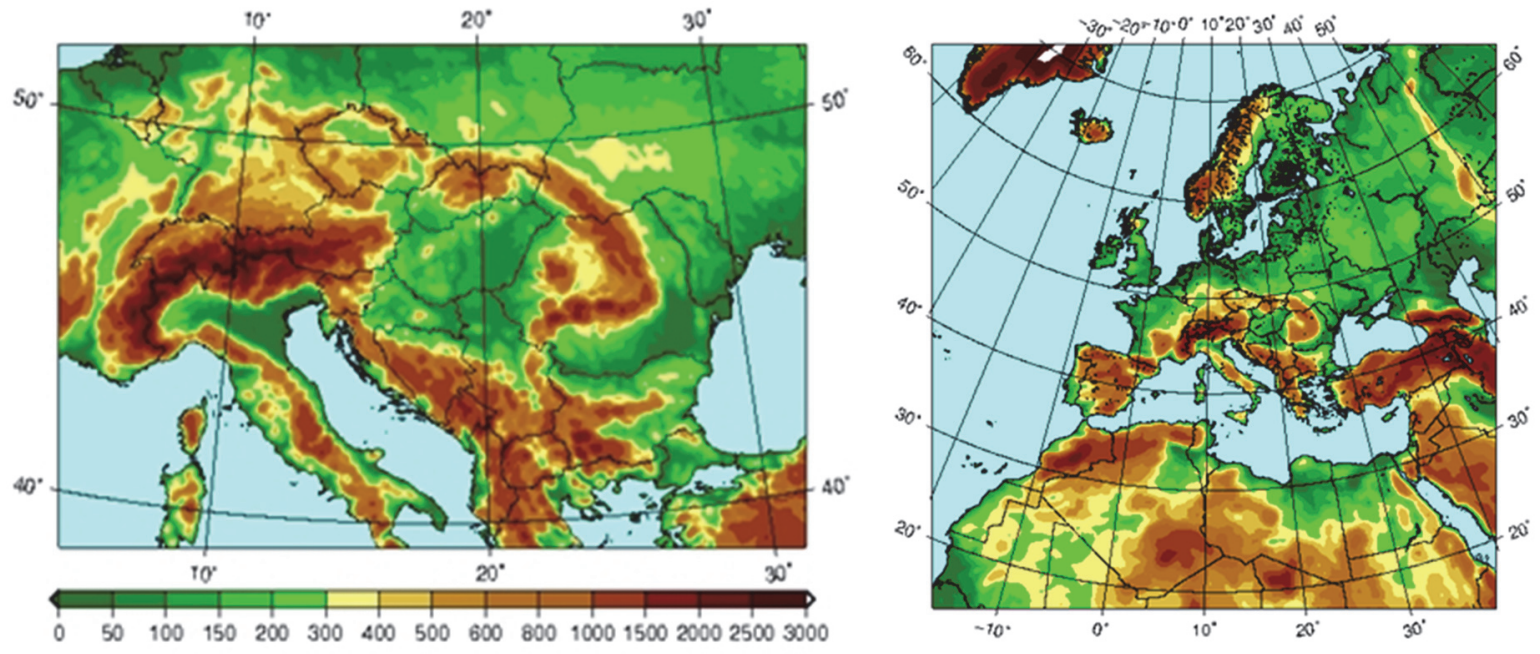

Fig 1. The integration domains of the $10 \mathrm{~km}$ horizontal resolution HMS-ALADIN52 regional climate model (left) and the $12.5 \mathrm{~km}$ horizontal resolution Euro-CORDEX regional climate models (right).

\subsection{The selected Euro-CORDEX simulations}

In addition to the assessment of HMS-ALADIN52 results, the projections of several Euro-CORDEX simulations are jointly evaluated, assuming that all of them are equally possible realizations of climate change. A multi-model and multi-scenario ensemble consisting of 26 simulations from the $12.5 \mathrm{~km}\left(0.11^{\circ} \times\right.$ $0.11^{\circ}$ ) Euro-CORDEX RCM set is selected to quantify the uncertainties originated from the GCM-RCM differences and the scenario choice. Eight RCMs driven by five GCMs (13 model combinations) using the RCP4.5 and RCP8.5 scenarios have been applied in this study (Table 2). The simulations (except two with CNRM-ALADIN63) were chosen several years ago based on the following criteria applied for the assessed variables: 1) the simulations should include the study period, 2) the historical and the two RCP scenario simulations should be available, 3) the simulations should be achieved on $0.44^{\circ}$ and $0.11^{\circ}$ resolution as well. The CNRM-ALADIN63 simulations were added afterwards in order to further explore the differences amongst the ALADIN versions. More details on the individual RCMs can be found in the reference articles. The domain of the simulations is presented in the right panel of Fig. 1 . 
Table 2. The ensemble selected from Euro-CORDEX with 13 model combinations driven by RCP4.5 and RCP8.5 scenarios (26 simulation members). The two ALADIN versions analyzed in detail are indicated with bold.

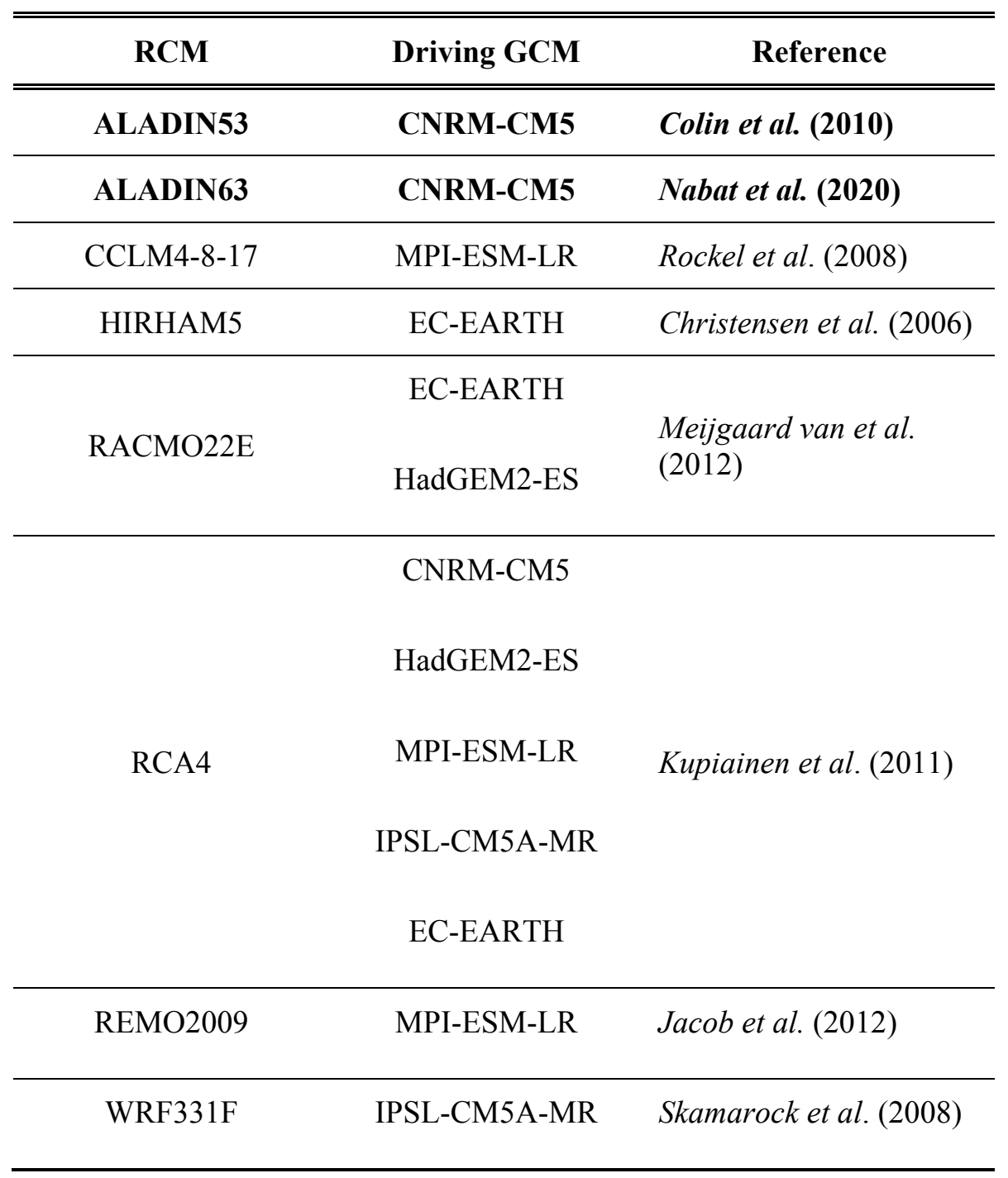

\subsection{Evaluation method}

The assessment concentrates on temperature and precipitation. First, the projections of HMS-ALADIN52 were thoroughly evaluated both over the whole model domain and Hungary. The annual and seasonal mean changes have been quantified in two future periods: 2021-2050 for the near future and 2071-2100 for the far future relative to the 1971-2000 model reference period. The Welchtest for both temperature and precipitation was performed to identify significant changes at grid points over Hungary.

In addition, the model results have been corrected by the delta method (Maraun, 2016; Maraun and Widmann, 2018) to filter out the systematic error of HMS-ALADIN52 (assuming that the past and future bias is unchanged), considering the CARPATCLIM-HU (Bihari et al., 2017) as a reference database. 
CARPATCLIM-HU is a daily gridded observation database on 0.1 degree horizontal resolution covering Hungary. The dataset was generated by the MASH homogenization (Szentimrey, 2008; 2014) and the MISH interpolation (Szentimrey and Bihari, 2007; 2014) methods specially developed for meteorological purposes, and it incorporates station measurements from Hungary and the neighboring countries For correction of the RCM results, the simulated monthly mean changes for each year in the projection time periods were combined with the observed 30-year monthly mean of the reference period (originated from CARPATCLIM-HU) in an additive way (according to Eq.(1)) for temperature and in a multiplicative way (according to Eq.(2)) for precipitation:

$$
\begin{gathered}
X(t)^{\prime}{ }_{s i m, f}=\bar{X}_{o b s, p}+\left(X(t)_{s i m, f}-\bar{X}_{s i m, p}\right), \\
X(t)^{\prime}{ }_{s i m, f}=\bar{X}_{o b s, p} \times\left(\frac{X(t)_{\text {sim }, f}}{\bar{X}_{s i m, p}}\right),
\end{gathered}
$$

where $X(t)^{\prime}{ }_{\text {sim, } f}$ is the bias-corrected future monthly mean value for the given year, $\bar{X}_{o b s, p}$ is the average of the observations for the reference period, $X(t)_{\text {sim, } f}$ is the simulated raw future value for a given year, and $\bar{X}_{s i m, p}$ is the average of simulated past values for the reference period. The yearly monthly means averaged over Hungary in the past and in the two future 30-year periods are shown in box-whisker diagrams (also known as boxplot; Williamson et al., 1989), in order to investigate how the range and distribution of monthly means change between the different 30-year periods. Five statistical attributes are visualized in a box-whisker diagram: the median, the lower and upper quartiles (i.e., the 25 th and 75 th percentiles), and the minimum and maximum values.

Finally, the HMS-ALADIN52 results have been compared to the EuroCORDEX experiments to examine how HMS-ALADIN52 fits into the uncertainty range of a larger ensemble, thus providing information on the representativeness of HMS-ALADIN52 in terms of temperature and precipitation changes over Hungary. This is an important step as there are limited opportunities to adapt and run several regional climate models in Hungary. The projected evolution of changes was assessed by using moving averages over 30-year time windows with one-year steps (e.g., 2021-2050, 2022-2051, etc.) throughout the 21 st century. Moreover, the mean temperature and precipitation changes for all models are presented together on scatter plots. The far future period in the case of Euro-CORDEX ensemble had to be slightly shifted to 2070-2099 instead of 2071-2100, because for some RCM simulations the year 2100 was missing due to the lack of GCM data. Nevertheless, shifting the 30-year period by one year does not affect the climate change signal significantly. 


\section{Results and discussion}

\subsection{In-house simulations with HMS-ALADIN52}

\section{Temperature}

A gradual warming can be detected towards the end of the century, which is more intense with the RCP8.5 than with the RCP4.5 scenario and in winter compared to summer (Fig. 2). Considering first the spatial pattern of temperature change on the model domain, the warming is increasing from southwest to northeast in summer. This also suggests that the continental parts are expected to experience higher temperature increases than the western, ocean-influenced parts. The temperature rise in the Ukrainian area (eastern part of the domain) could reach $5{ }^{\circ} \mathrm{C}$ by the end of the century with the RCP8.5 scenario and $3-3.5{ }^{\circ} \mathrm{C}$ with RCP4.5. The smallest temperature rise $\left(0.5-1{ }^{\circ} \mathrm{C}\right)$ can occur in 2021-2050 with RCP4.5 over the central part of Germany and the northwestern part of Switzerland. Moreover, the Alps are emerging with higher temperature increase (reaching around $7{ }^{\circ} \mathrm{C}$ for the RCP8.5 scenario) from its surrounding areas as well. In general, the spatial differences are larger with both scenarios at the end of the century in contrast to the middle of the century. In winter, the Alpine chains do not appear as prominent as in summer, but the largest temperature increase is expected also over Ukraine, and several smaller regions (e.g., Po Plain, South Germany, Czech Republic) may face remarkable warming too, reaching $7-8{ }^{\circ} \mathrm{C}$ by $2071-2100$ with RCP8.5 and 5-6 ${ }^{\circ} \mathrm{C}$ with RCP4.5.

The mean temperature increase for the area of Hungary is summarized in Table 3. Annually $1.3{ }^{\circ} \mathrm{C}$ in $2021-2050,2.9^{\circ} \mathrm{C}$ in $2071-2100$ with RCP4.5 is obtained, respectively, which could reach $4{ }^{\circ} \mathrm{C}$ by the end of the century with RCP8.5. The largest seasonal temperature increase occurs in winter: $3.6{ }^{\circ} \mathrm{C}$ and $4.8^{\circ} \mathrm{C}$ by the end of the century with RCP4.5 and RCP8.5, respectively. A slight zonality in the warming can be noticed in winter with all scenarios and for all periods with higher values over the northern and northeastern parts of the country, especially over the North Hungarian Mountains (Fig. 2). The second most warming season is summer: $2.9{ }^{\circ} \mathrm{C}$ and $4.4{ }^{\circ} \mathrm{C}$ by the end of the century with RCP4.5 and RCP8.5, respectively, and the warming in this season is almost homogeneous in terms of the spatial pattern. The change is mostly significant at both annual and seasonal scales at all grid points (not shown).

Monthly mean temperature values averaged over Hungary are analyzed to gain information on the variability within the selected 30-year periods. The warming in February, August, September, and December using the RCP8.5 scenario (red boxes in Fig. 3) is so large, that the monthly values between the 25th and 75 th percentiles (which are in the boxes) do not even overlap in the two 30 -year periods. The highest value among the mean temperatures of July - which month was the warmest in the reference period - was $23.2^{\circ} \mathrm{C}$, this can exceed $29^{\circ} \mathrm{C}$ by the end of the century. Based on the percentiles, for both future periods 
and both scenarios, the mean temperature in July may become much more variable compared to the reference period: the wider boxes indicate that the range of values between the 25 th and 75 th percentiles may become extended. August can compete with July in terms of the hottest month in the year on average $\left(\max .30 .1^{\circ} \mathrm{C}\right)$ in 2071-2100 with the higher emission scenario. Mean temperature values not exceeding 0 Celsius degree are still possible to occur in the winter months in 2021-2050 with both scenarios and in 2071-2100 with RCP4.5, but the $75 \%$ of the monthly means will reach 0 degree considering all the three months.

The key difference of temperature increase with RCP4.5 and RCP8.5 scenarios, that is especially clear in the far future, reveals the strong correlation between the radiative forcing and the temperature change.
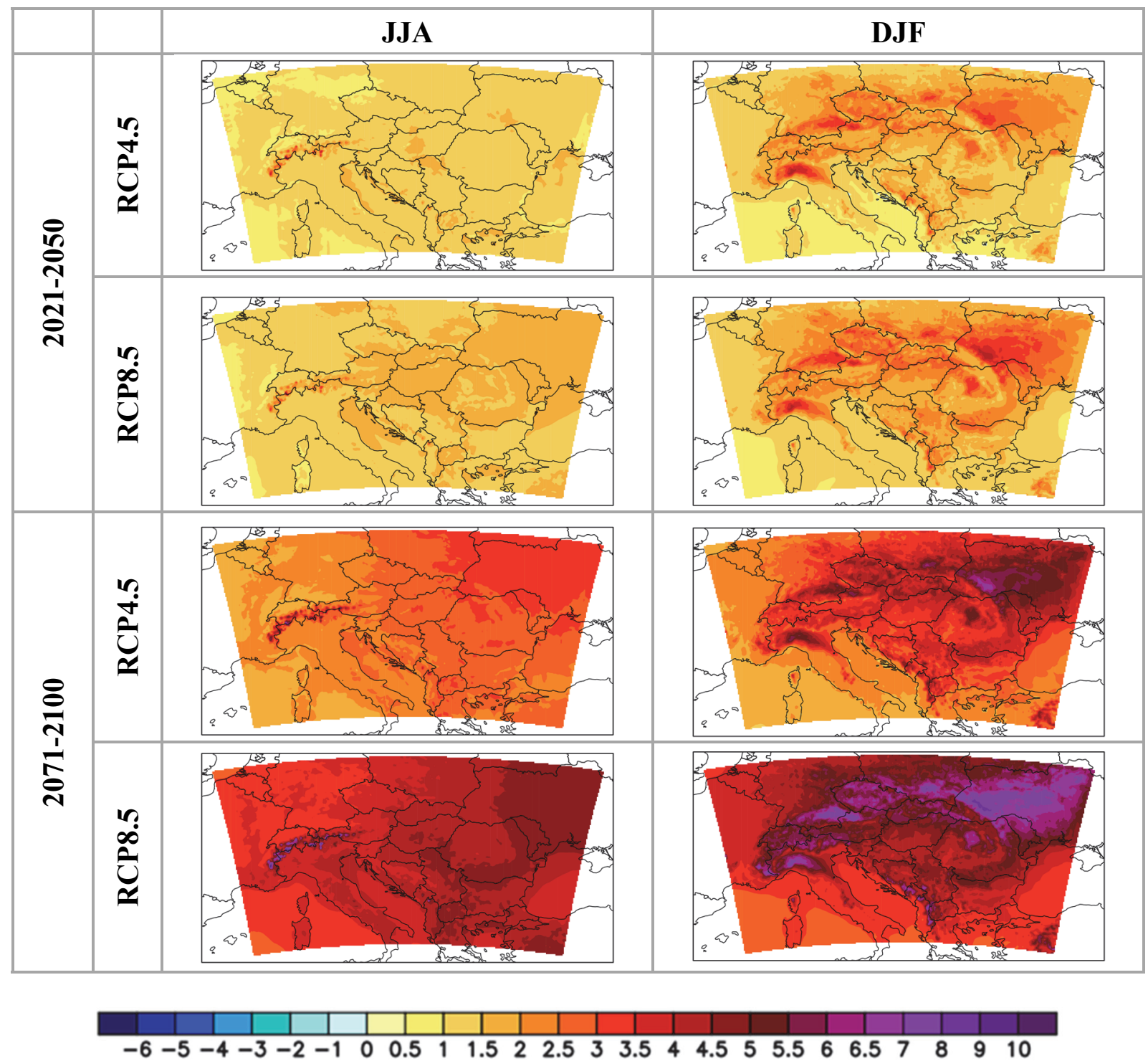

Fig. 2. Summer (JJA) and winter (DJF) temperature changes $\left({ }^{\circ} \mathrm{C}\right)$ projected for $2021-2050$ and 2071-2100 over the domain of HMS-ALADIN52 in case of RCP4.5 and RCP8.5 scenarios (reference period: 1971-2000). 
Table 3. Annual and seasonal mean temperature changes $\left({ }^{\circ} \mathrm{C}\right)$ in Hungary for $2021-2050$ and 2071-2100 compared to 1971-2000, based on the results of HMS-ALADIN52 model simulations with RCP4.5 and RCP8.5 scenarios, below them the corresponding minimum and maximum changes are in parentheses based on 26 Euro-CORDEX (EC) ensemble simulations.

\begin{tabular}{|c|c|c|c|c|c|c|}
\hline & & Annual & МАМ & JJA & SON & DJF \\
\hline \multirow{2}{*}{ 2021-2050 } & RCP4.5 & $\begin{array}{c}1.3 \\
{[0.9-2.2]}\end{array}$ & $\begin{array}{c}1.1 \\
{[0.5-2.4]}\end{array}$ & $\begin{array}{c}1.4 \\
{[1.0-2.1]}\end{array}$ & $\begin{array}{c}0.8 \\
{[0.5-2.0]}\end{array}$ & $\begin{array}{c}1.8 \\
{[0.6-2.5]}\end{array}$ \\
\hline & RCP8.5 & $\begin{array}{c}1.7 \\
{[0.8-2.4]}\end{array}$ & $\begin{array}{c}1.3 \\
{[0.9-2.2]}\end{array}$ & $\begin{array}{c}1.7 \\
{[0.8-2.5]}\end{array}$ & $\begin{array}{c}1.5 \\
{[0.8-2.7]}\end{array}$ & $\begin{array}{c}2.1 \\
{[0.2-2.8]}\end{array}$ \\
\hline \multirow{2}{*}{$\begin{array}{c}\text { 2071-2100 } \\
\text { (EC: 2070- } \\
2099)\end{array}$} & RCP4.5 & $\begin{array}{c}2.9 \\
{[1.3-3.3]}\end{array}$ & $\begin{array}{c}2.7 \\
{[1.1-3.1]}\end{array}$ & $\begin{array}{c}2.9 \\
{[1.5-3.3]}\end{array}$ & $\begin{array}{c}2.3 \\
{[1.1-3.5]}\end{array}$ & $\begin{array}{c}3.6 \\
{[1.0-3.9]}\end{array}$ \\
\hline & RCP8.5 & $\begin{array}{c}4.0 \\
{[3.2-5.7]}\end{array}$ & $\begin{array}{c}3.4 \\
{[2.6-5.0]}\end{array}$ & $\begin{array}{c}4.4 \\
{[3.2-5.8]}\end{array}$ & $\begin{array}{c}3.5 \\
{[2.7-5.9]}\end{array}$ & $\begin{array}{c}4.8 \\
{[3.4-6.1]}\end{array}$ \\
\hline
\end{tabular}

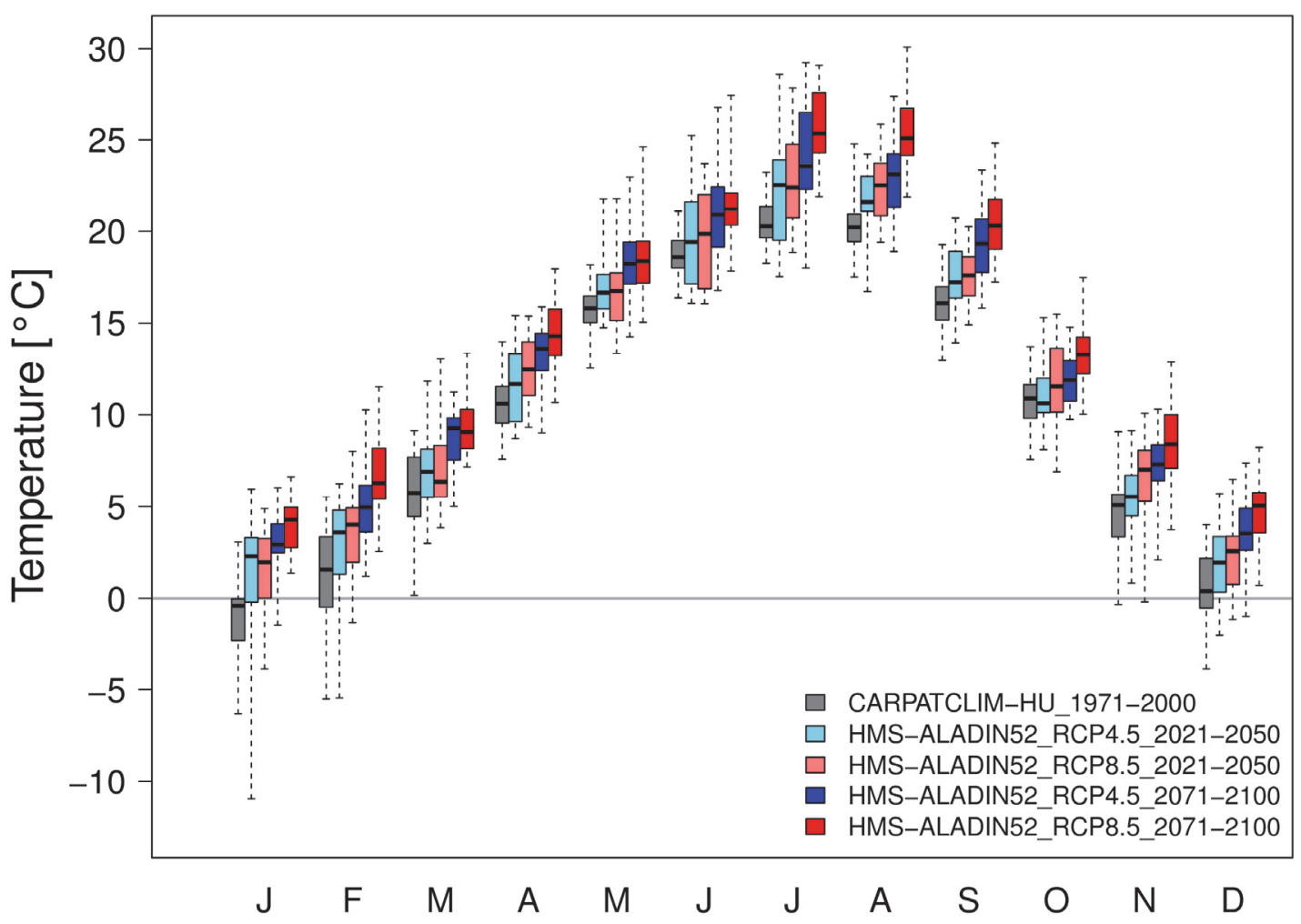

Fig. 3. Box-whisker diagram of the bias-corrected monthly mean temperature values $\left({ }^{\circ} \mathrm{C}\right)$ areaaveraged over Hungary for every year of 2021-2050 and 2071-2100 (light and dark colors respectively) obtained with the RCP4.5 and RCP8.5 scenarios driven HMS-ALADIN52 (blue and red, respectively). The observations (CARPATCLIM-HU) for 1971-2000 are indicated with grey. The lower and upper boundaries of the rectangles (the "boxes") represent the lower and upper quartiles of the dataset (25th and 75th percentiles, respectively), while the line in the boxes shows the median value. The vertical dashed lines below and above the boxes show the minimum and maximum values of the dataset. 


\section{Precipitation}

The winter and summer mean precipitation changes over the model domain are presented for both future time periods considering both scenarios in Fig. 4. The simulation results suggest a precipitation increase both in summer and winter, for a large part of the domain, including Hungary. In summer, heavy increase $(>70 \%)$ - which can be caused by an inaccuracy in the SST forcing field (CNRM, personal communication) - is projected over the Black Sea, Adriatic Sea, and Aegean Sea with both scenarios.

Over Hungary, the relative precipitation increase can reach $16-24 \%$ by the end of the century on annual scale (Table 4), which is significant in most of the grid cells for both future periods with RCP4.5 and RCP8.5, except above Lake Balaton in 2071-2100 and over a western region in Hungary in 2021-2050 with the RCP4.5 scenario (not shown). Considering seasonal mean changes, relative precipitation increase occurs in all seasons, moreover, larger increase is expected in the far future period and with RCP8.5, except in spring and summer with $\mathrm{RCP} 4.5$, when the magnitude of precipitation change remains nearly the same between the two future periods. Precipitation change between 2021-2050 and 2071-2100 is the strongest in autumn, and considering RCP8.5, this season may face the most precipitation surplus in the year $(23$ and $33 \%$ in the near and far future, respectively). The smallest increase is expected in spring with the RCP4.5 scenario: $9 \%$ for $2021-2050$ and $10 \%$ for $2071-2100$. Note that gridpoints with higher relative seasonal increase (reaching around 20\%) are generally significant areas, while areas of decrease occurring only with RCP4.5 are not significant (except 1-2 grid cells) and may appear over small regions like Lake Balaton in summer and spring of both future period, and like some parts of the Somogyi Hills and the North Hungarian Mountains in autumn of 2021-2050 (not shown). It should also be noted that no explicit lake parameterization is used in the model, so, for example, results over Lake Balaton should be treated with caution in terms of both temperature and precipitation.

The monthly means for each year of the 30 -year period indicates large interannual variability (Fig. 5) according to the spread of the values. The maximum for the future is expected in June like in the reference period, but it can be even wetter in the 21 st century: the amount can reach $65-120 \mathrm{~mm}$ considering the 25 th and 75th percentiles for the end of the century, while it varied between $50-85 \mathrm{~mm}$ in 1971-2000 according to the CARPATCLIM-HU. In addition, HMSALADIN52 simulations show the largest spread of monthly precipitation amounts in August. February was usually the driest month in the past, and it seems likely to be shifted to March in future. September was also a particularly dry month on average in 1971-2000, while a secondary maximum occurred in November. In comparison, the future monthly values suggest that mainly September is responsible for the autumn precipitation increase, moreover, the secondary maximum appears also in this month. The very low (near-zero) monthly precipitation sums occurred between 1971 and 2000 are not likely to disappear in 
the 21 st century, moreover, near-zero monthly sums are possible both in the near and far future. The maximums can vary between 50 and $240 \mathrm{~mm}$ depending on the considered month, and it suggests that much higher monthly precipitation amounts could occur even in the near future than have been observed in the past.
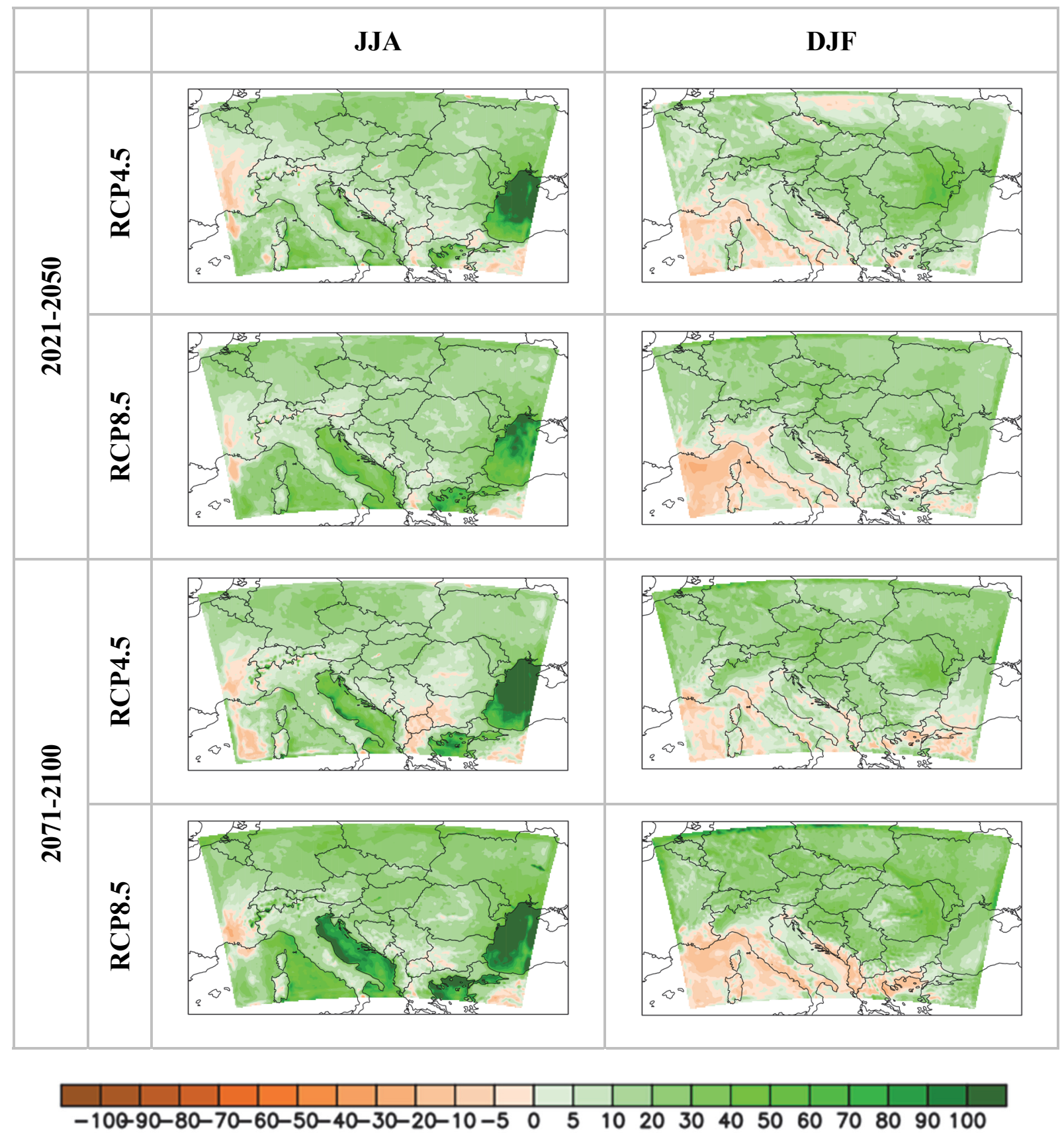

Fig. 4. Summer (JJA) and winter (DJF) relative precipitation changes (\%) projected for 20712100 over the domain of HMS-ALADIN52 in case of RCP4.5 and RCP8.5 scenarios (reference period: 1971-2000). 
Table 4. Annual and seasonal mean precipitation relative changes (\%) in Hungary for 2021-2050 and 2071-2100 compared to 1971-2000, based on the results of HMSALADIN52 model simulations with RCP4.5 and RCP8.5 scenarios, below them the corresponding minimum and maximum changes are in parentheses based on 26 EuroCORDEX (EC) RCM simulations.

\begin{tabular}{|c|c|c|c|c|c|c|}
\hline & & Annual & МАМ & JJA & SON & DJF \\
\hline \multirow{2}{*}{ 2021-2050 } & RCP4.5 & $\begin{array}{c}13 \\
{[-4-13]}\end{array}$ & $\begin{array}{c}9 \\
{[-5-21]}\end{array}$ & $\begin{array}{c}17 \\
{[-16-15]}\end{array}$ & $\begin{array}{c}9 \\
{[-11-21]}\end{array}$ & $\begin{array}{c}18 \\
{[5-24]}\end{array}$ \\
\hline & RCP8.5 & $\begin{array}{c}17 \\
{[0-16]}\end{array}$ & $\begin{array}{c}13 \\
{[-1-26]}\end{array}$ & $\begin{array}{c}15 \\
{[-8-23]}\end{array}$ & $\begin{array}{c}23 \\
{[-7-19]}\end{array}$ & $\begin{array}{c}19 \\
{[-5-26]}\end{array}$ \\
\hline \multirow{2}{*}{$\begin{array}{c}\text { 2071-2100 } \\
\text { (EC: 2070- } \\
2099)\end{array}$} & RCP4.5 & $\begin{array}{c}16 \\
{[0-18]}\end{array}$ & $\begin{array}{c}10 \\
{[1-29]}\end{array}$ & $\begin{array}{c}16 \\
{[-16-17]}\end{array}$ & $\begin{array}{c}23 \\
{[-1-25]}\end{array}$ & $\begin{array}{c}22 \\
{[4-29]}\end{array}$ \\
\hline & RCP8.5 & $\begin{array}{c}24 \\
{[3-37]}\end{array}$ & $\begin{array}{c}19 \\
{[-2-32]}\end{array}$ & $\begin{array}{c}24 \\
{[-19-48]}\end{array}$ & $\begin{array}{c}33 \\
{[0-60]}\end{array}$ & $\begin{array}{c}24 \\
{[17-53]}\end{array}$ \\
\hline
\end{tabular}

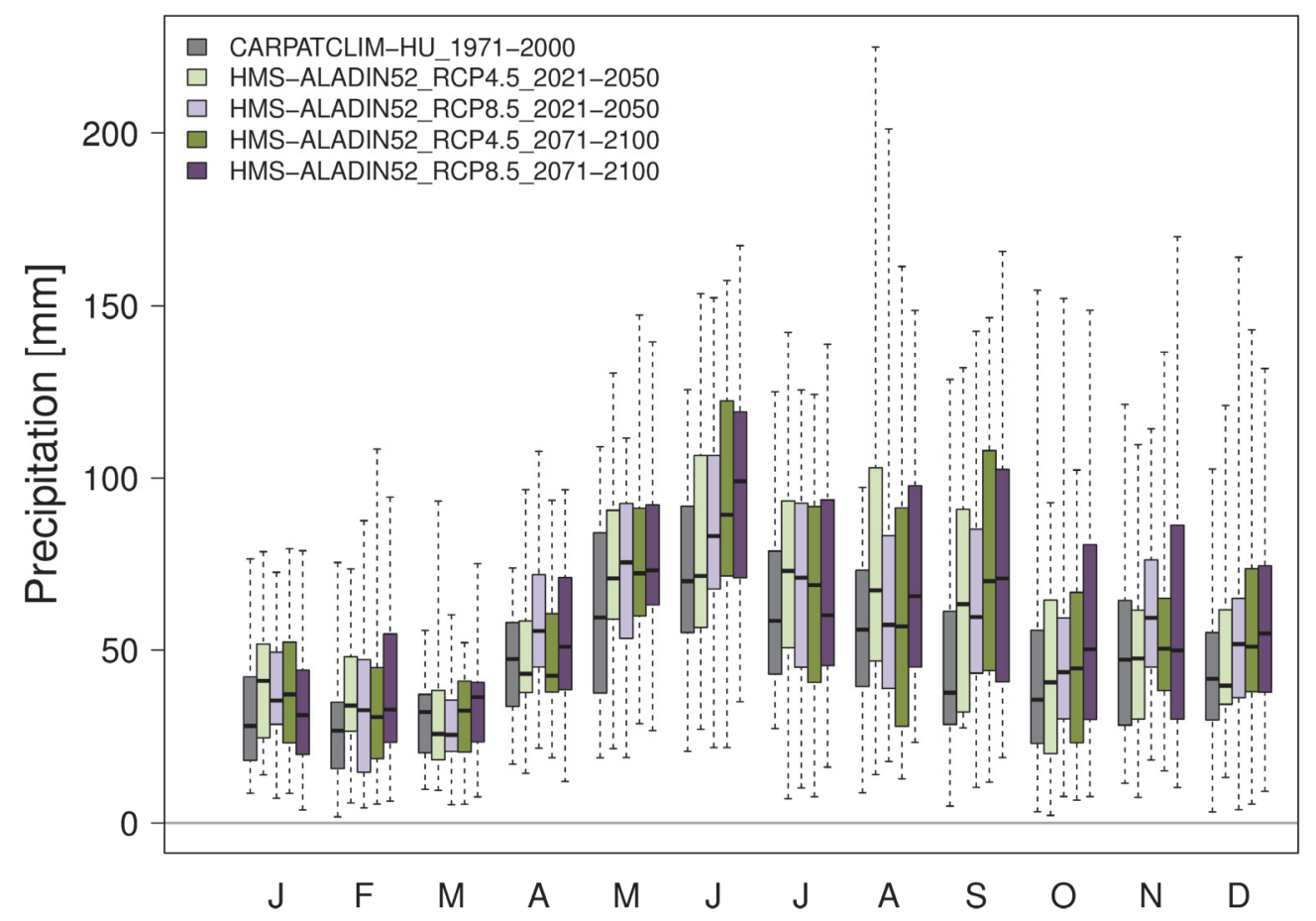

Fig. 5. Box-whisker diagram of the bias-corrected monthly precipitation sums (mm/month) area-averaged over Hungary for every year of 2021-2050 and 2071-2100 (light and dark colors, respectively), obtained with the RCP4.5 and RCP8.5 scenarios driven HMS-ALADIN52 (green and purple, respectively). The observations (CARPATCLIM-HU) for 1971-2000 are indicated with grey. The lower and upper boundaries of the rectangles (the "boxes") represent the lower and upper quartiles of the dataset (25th and 75th percentiles, respectively), while the line in the boxes shows the median value. The vertical dashed lines below and above the boxes show the minimum and maximum values of the dataset. 


\subsection{Comparison to Euro-CORDEX model ensemble}

Based on the results of the selected Euro-CORDEX simulations (for the calculated minimum-maximum ranges of the annual and seasonal mean temperature and precipitation changes for the investigated 30-year periods see Tables 3 and 4), the projected annual mean temperature change for Hungary lies approximately in the same range (within $0.8{ }^{\circ} \mathrm{C}$ and $2.4{ }^{\circ} \mathrm{C}$ ) with both scenarios for the near future, while for $2070-2099$, their ranges seem to be almost disjoint: $1.3-3.3^{\circ} \mathrm{C}$ for RCP4.5 and 3.2-5.7 ${ }^{\circ} \mathrm{C}$ for RCP8.5 (see Table 3 and also the box-whisker on the right side of Fig. 8). Jacob et al. (2014) also concluded that a robust and statistically significant warming, in the range of $1-4.5{ }^{\circ} \mathrm{C}$ for RCP4.5 and of $2.5-5.5^{\circ} \mathrm{C}$ for RCP8.5 is likely to occur on a European scale, with regional differences.

Considering the maxima of the projected temperature changes by the EuroCORDEX models (Table 3), the largest warming may occur in winter in both future periods, with both scenarios. However, the spread of the model results is also the highest in this season (except with the RCP8.5 in the end of the century), which makes winter a highly uncertain season in terms of the magnitude of changes. In contrast, the lowest change is seen in spring (except in 2021-2050 with RCP4.5 scenario). Recall, that the largest warming was projected in winter by HMS-ALADIN52 as well, while the least warming season was spring and autumn using RCP8.5 and RCP4.5, respectively.

The projected precipitation change for both scenarios in the near future and also for the RCP4.5 scenario in 2070-2099 lies in the same range, namely between $-16 \%$ and $+29 \%$. (Table 4 ). Only the RCP 8.5 for the far future projects somewhat higher values: except for spring, the maximum of the Euro-CORDEX ensemble is between $48-60 \%$ depending on the seasons, but it must be added that only one model is responsible for such high values in each season (Fig. 7). For both future periods, most of the model simulations show seasonal precipitation increase (reinforcing the HMS-ALADIN52 precipitation projections) except autumn in 2021-2050 and summer. The sign of the summer change is uncertain in the EuroCORDEX results, i.e., both increase and decrease are projected. The concluded tendencies are in good agreement with the findings of Kis et al. (2020) on a monthly scale, even though they performed their analysis for a different multimodel ensemble - 10 RCMs driven by 4 different GCMs with 3 RCPs (RCP2.6, RCP4.5, and RCP8.5).

Looking at the scatter plots of projected precipitation and temperature changes over Hungary, we hardly see any correlation between them neither for 2021-2050 (Fig. 6) nor for 2070-2099 (Fig. 7), and the sign of precipitation change is uncertain in some seasons. Hawkins and Sutton (2011) showed that the internal variability and model uncertainty have higher contribution to the total uncertainty of the near-future temperature projections, while the scenario choice has higher role in the second half of the century. This is valid also for Hungary: 
while the symbols representing the changes are grouped in a small circle for 20212050 in Fig. 6, for 2070-2099 in Fig. 7 they are clearly distributed between two groups based on the applied RCP scenarios in each season. Szabó and Szépszó (2016) proved using global climate model results, that the main uncertainty source of precipitation projections over the Carpathian Basin is the internal variability along the whole century, and the scenarios choice has the smallest contribution to the total uncertainty range. Our results coincide with this for Hungary: low and high precipitation change as well as positive and negative precipitation changes are equally projected both using RCP4.5 and RCP8.5 scenarios. The only exception is winter in the far future: higher precipitation increase is shown mostly by RCP8.5 simulations (accompanied also by higher temperature change). This outcome for winter contradicts the conclusion of Szabó and Szépszó (2016) which did not show any impact of the scenario choice on the winter precipitation change signal over the Carpathian Basin, however, their study was based solely on GCM outputs.
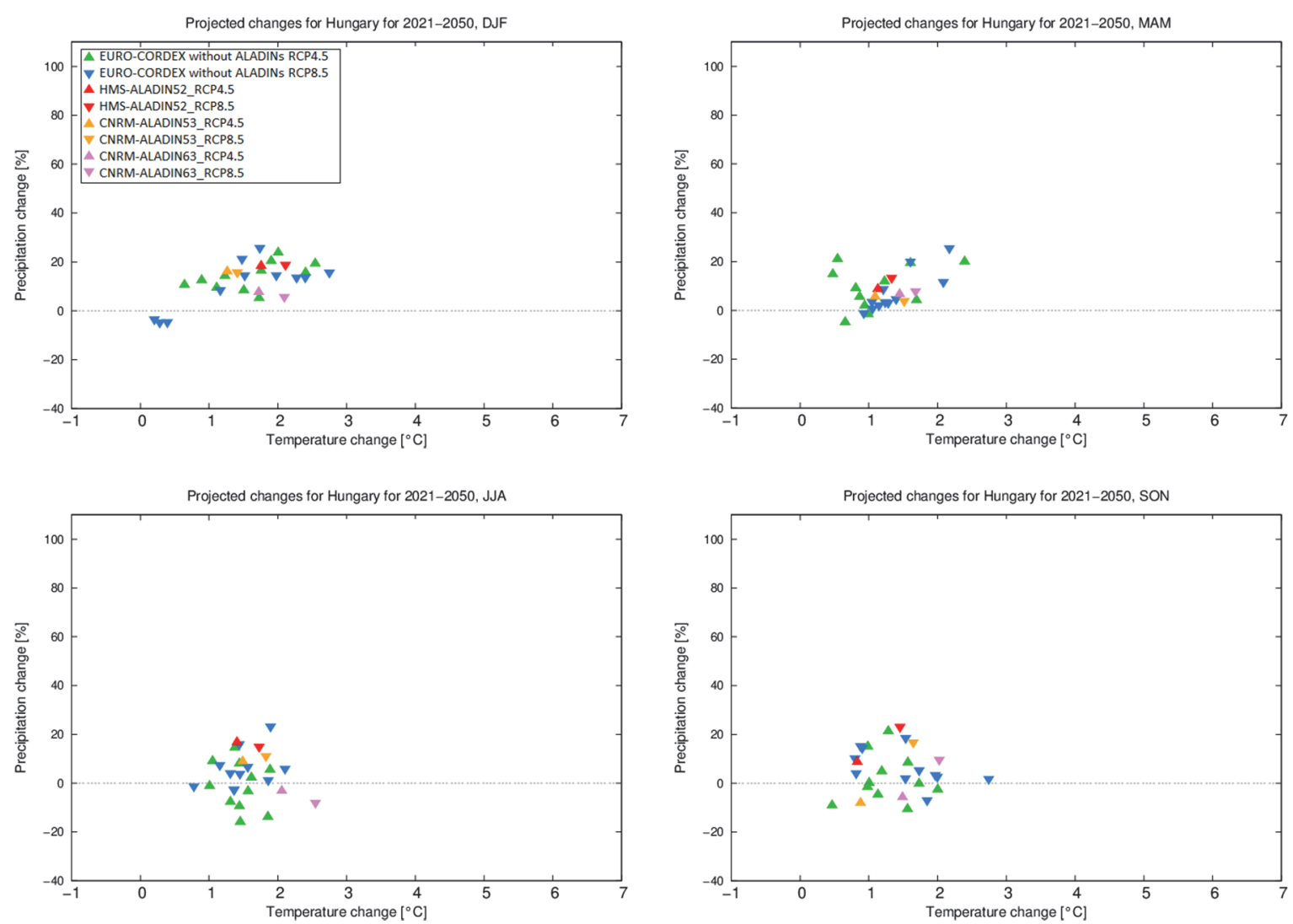

Fig. 6. Scatter plots of projected seasonal (winter-DJF: upper left, spring-MAM: upper right, summer-JJA: lower left, autumn-SON: lower right) changes of precipitation (y-axis; in \%) and temperature (x-axis; in ${ }^{\circ} \mathrm{C}$ ) over Hungary according to the different RCP scenarios (represented by different shapes) for 2021-2050 based on 26 Euro-CORDEX RCM simulations (highlighting CNRM-ALADINs) and HMS-ALADIN52. The reference period is 1971-2000. 

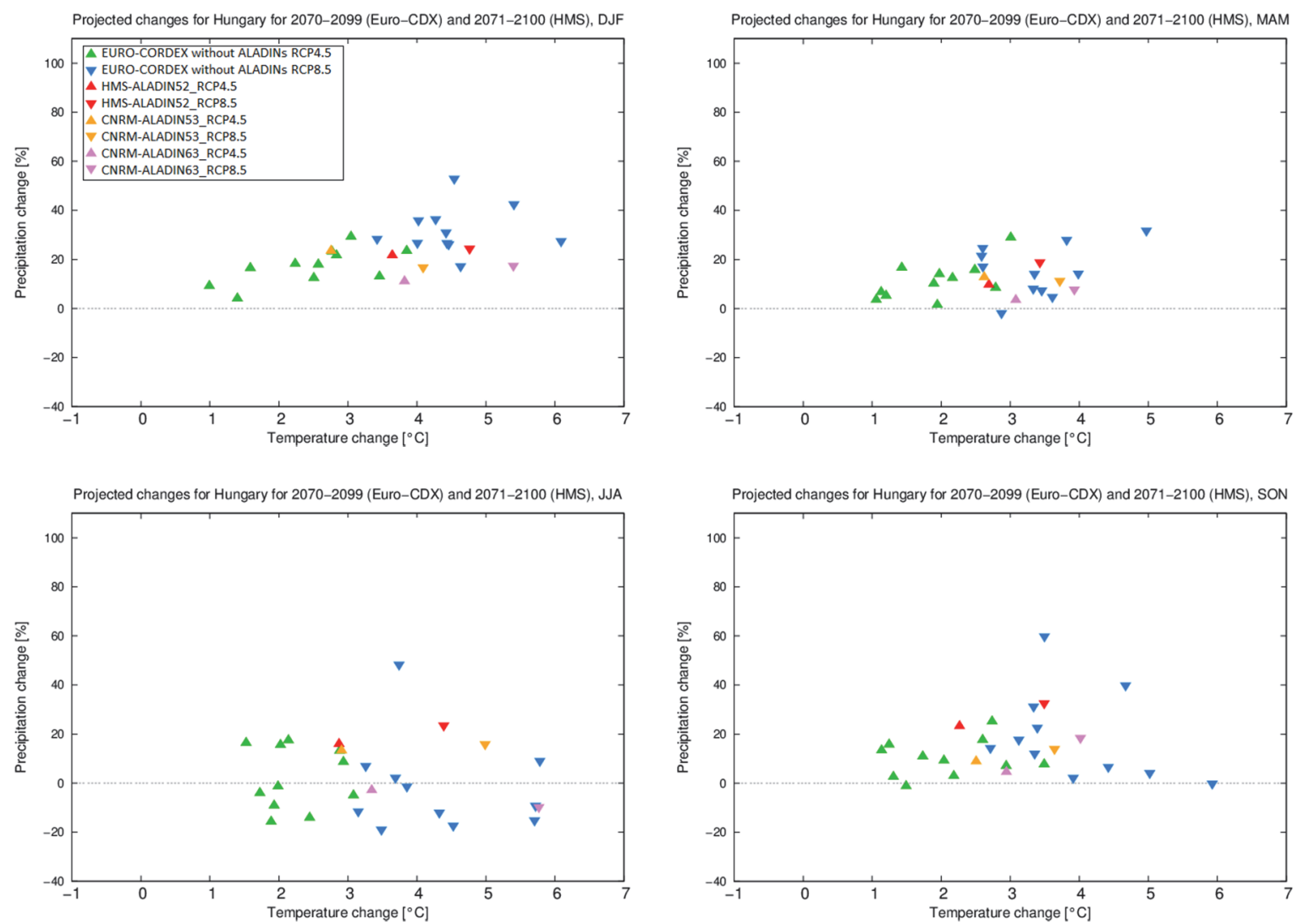

Fig. 7. Scatter plots of projected seasonal (winter-DJF: upper left, spring-MAM: upper right, summer-JJA: lower left, autumn-SON: lower right) changes of precipitation (y-axis; in \%) and temperature (x-axis; in ${ }^{\circ} \mathrm{C}$ ) over Hungary according to the different RCP scenarios (represented by different shapes) for 2070-2099 based on 26 Euro-CORDEX RCM simulations (highlighting CNRM-ALADINs) and for 2071-2100 for HMS-ALADIN52. The reference period is $1971-2000$.

Finally, results of the three ALADIN versions are assessed and compared to the Euro-CORDEX subset. Focusing on the annual temperature change (Fig. 8), CNRM-ALADIN53 with the RCP4.5 is quite similar to HMS-ALADIN52, but the former one projects somewhat lower temperature change throughout the $21 \mathrm{st}$ century. In contrast, with the RCP8.5 scenario, CNRM-ALADIN53 produces almost the same warming as HMS-ALADIN52. Looking at the scatter plots of seasonal changes (Figs. 6 and 7), it is clear that the largest difference between the two model versions occurs in winter with both scenarios. Note that the RCP8.5 driven HMS-ALADIN52 projects lower temperature increase than CNRMALADIN53 in spring, summer, and autumn, which may contribute to the very similar results on annual scale. Considering all the ALADINs, the RCP4.5 scenario driven simulations indicate more intense warming compared to the RCP8.5 driven counterparts in the early part of the century (Fig. 8). 
Comparing the temperature projections of the different ALADIN versions to the 26 members Euro-CORDEX ensemble in the 21 st century over Hungary (see Fig. 8), while HMS-ALADIN52 with RCP4.5 tends to alternate around the median of the Euro-CORDEX ensemble during the whole time span, with the RCP8.5 scenario it remains below the median till 2040, but then increasingly exceeds it. CNRM-ALADIN63's projection is above the ensemble median, both with RCP4.5 and RCP8.5 scenarios thanks to its larger warming. The concluded features seem to be logical, because HMS-ALADIN52 and CNRM-ALADIN53 are consistent regarding the physical parameterization package, while CNRMALADIN63 is quite different, as large part of the parameterization has been changed in that version. We also should remember that HMS-ALADIN52 and CNRM-ALADIN53 share the same LBC error during the historical period, whereas this error was corrected in CNRM-ALADIN63 (see Section 2.2).

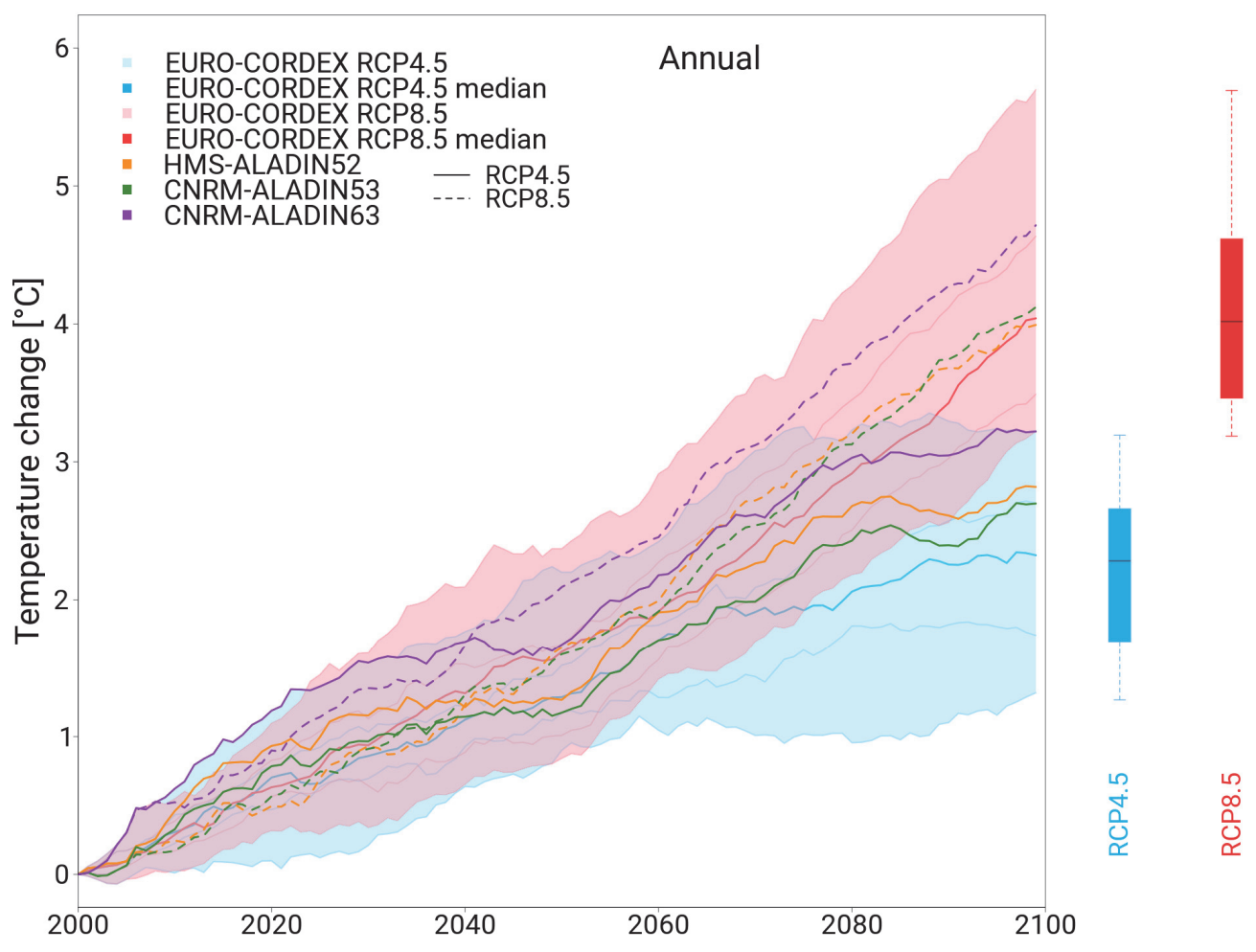

Fig. 8. The temporal evolution of the annual mean temperature change $\left({ }^{\circ} \mathrm{C}\right)$ over Hungary in the 21 st century under the RCP4.5 and RCP 8.5 scenarios based on 26 Euro-CORDEX RCM simulations, smoothed with a 30 -year window moving average. The median of these simulations is indicated with blue and red lines, the spread of these simulations is indicated with blue and pale red shades for the RCP4.5 and RCP8.5 scenarios, respectively. The thin blue and pale red lines represent the 25th and 75th percentiles. HMS-ALADIN52, CNRM-ALADIN53, and CNRM-ALADIN63 with RCP4.5 (solid line) and RCP8.5 (dashed line) are indicated with different colors. (The calculated average values are plotted at the final year of the time interval.) On the right, the box-whisker diagram of the Euro-CORDEX simulations sorted by the different scenarios is shown for 2070-2099. The reference period is 1971-2000. 
Regarding the temporal evolution of the precipitation changes in the $21 \mathrm{st}$ century, two seasonal examples are shown (Fig. 9). In winter, CNRM-ALADIN63 is below the ensemble median with both scenarios. HMS-ALADIN52 and CNRMALADIN53 behave similarly to each other, and project larger precipitation increase than CNRM-ALADIN63, which difference is reduced by the end of the century. Note that at the beginning of the century, HMS-ALADIN52 shows higher mean precipitation values than even the maximum of the Euro-CORDEX ensemble. By the end of the century, the HMS-ALADIN52 and CNRMALADIN53 versions project approximately the same winter precipitation increase as the median of the Euro-CORDEX ensemble considering RCP4.5 scenario. This is also true for the RCP8.5-driven HMS-ALADIN52, but CNRM-ALADIN53 is shifted away from the median and projects lower values. During summer, CNRMALADIN63 indicates precipitation decrease with both RCPs in 2021-2050 and 2071-2100 (Figs. 6 and 7) in contrast to HMS-ALADIN52 and CNRMALADIN53. However, looking at the whole century (Fig. 9), especially with $\mathrm{RCP} 8.5$, a few 30-year time periods may face precipitation surplus compared to the past. Assessing the ALADIN versions in light of the Euro-CORDEX ensemble, HMS-ALADIN52 with the RCP8.5 scenario sticks out from the spread for some short time intervals. The extent of the uncertainties is much larger for the summer season than for winter (just as the box-whisker diagrams on the right side of Fig. 9 clearly indicate this for 2070-2099). The RCP8.5 results completely cover the ensemble uncertainty by the end of the century, underlining the irrelevance of the scenario choice. However, it is also important to note that the maximum of the summer change is provided by the WRF331F simulation which is responsible for about the upper $20 \%$ of the range from 2080 in case of RCP8.5 scenario. In autumn (not shown) and winter, this member gives also the maximum of the RCP8.5 range. The WRF331F simulation should be treated with caution, as it has been removed from several national and international model ensembles due to its problematic behavior (Giorgi et al., 2016; Vautard et al., 2021). 

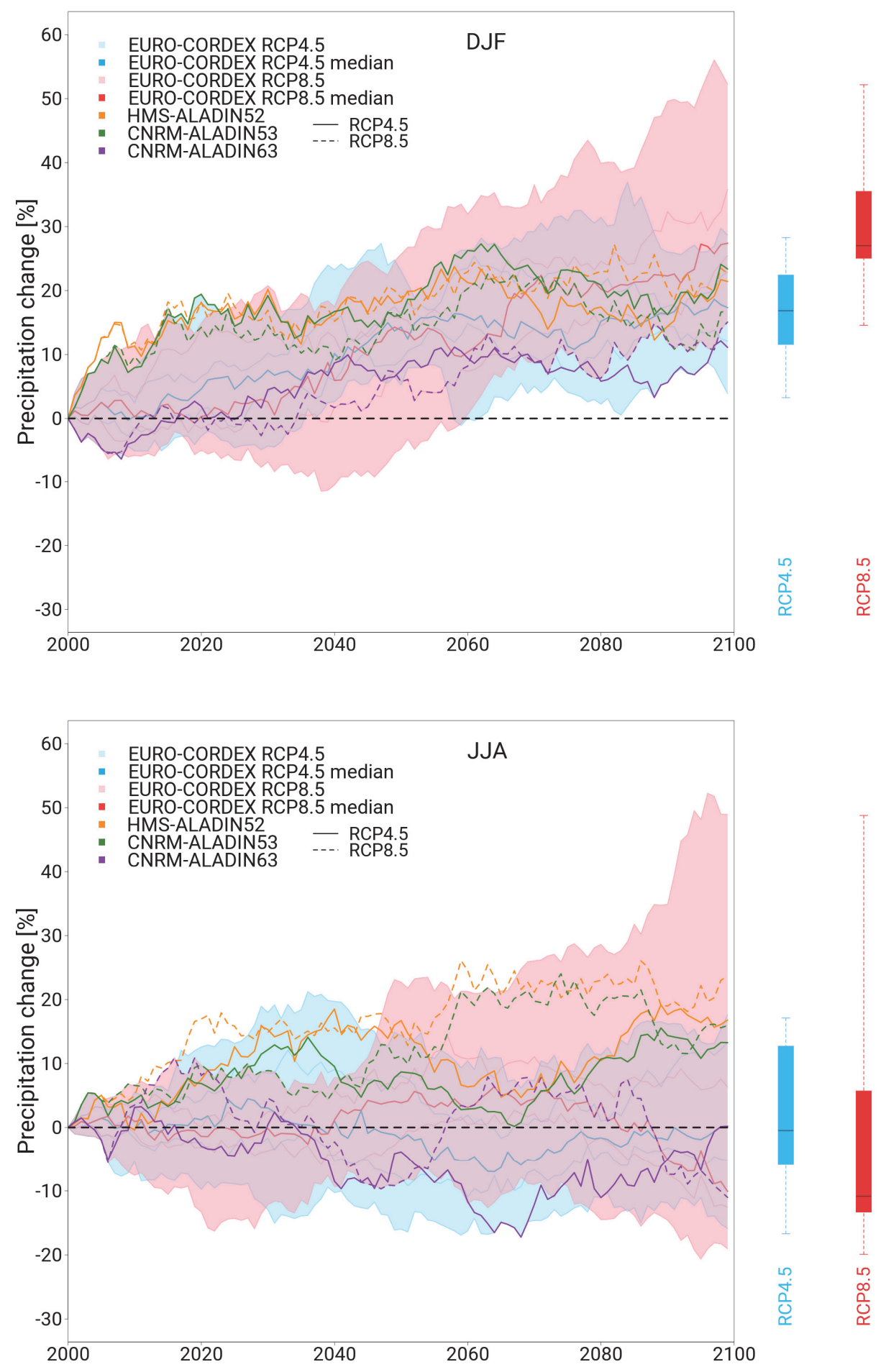

Fig. 9. The temporal evolution of the winter (DJF, top) and summer (JJA, bottom) mean precipitation changes (\%) over Hungary in the 21st century under the RCP4.5 and RCP8.5 scenarios based on 26 Euro-CORDEX RCM simulations, smoothed with a 30-year window moving average. The median of these simulations is indicated with blue and red lines, the spread of these simulations is indicated with blue and pale red shades for the RCP4.5 and RCP8.5 scenarios, respectively. The thin blue and pale red lines represent the 25 th and 75 th percentiles. HMS-ALADIN52, CNRM-ALADIN53, and CNRM-ALADIN63 with RCP4.5 (solid line) and RCP8.5 (dashed line) are indicated with different colors. (The calculated average values are plotted at the final year of the time interval.) On the right, the box-whisker diagram of the Euro-CORDEX simulations sorted by the different scenarios is shown for 2070-2099. The reference period is $1971-2000$. 


\section{Summary and conclusions}

In this paper, the history and some recent temperature and precipitation results of the ALADIN-Climate regional climate model used at HMS have been summarized. In addition to HMS-ALADIN52 simulations, a Euro-CORDEX ensemble (which includes two additional versions of ALADIN-Climate) has been studied in order to evaluate the climate change expected in Hungary and to assess the representativeness of HMS-ALADIN52. The results of three ALADINClimate models (HMS-ALADIN52, CNRM-ALADIN53, CNRM-ALADIN63) included in this study were evaluated with special focus. Temperature and precipitation changes are analyzed mainly for 2021-2050 and 2071-2100 (20702099 for Euro-CORDEX) with respect to 1971-2000 but for the whole 21th century as well along RCP4.5 and RCP8.5 scenarios.

The HMS-ALADIN52 results for Hungary can be considered representative for temperature: the gradual increase is significant, the annual mean change is close to the median of the Euro-CORDEX simulations. The main source of uncertainty in the second half of the century is the scenario choice (Szabó and Szépszó, 2016) which is confirmed by the results. According to the EuroCORDEX, the annual mean temperature increase is more moderate with RCP4.5 varying between $1.3{ }^{\circ} \mathrm{C}$ and $3.3{ }^{\circ} \mathrm{C}\left(2.9{ }^{\circ} \mathrm{C}\right.$ in HMS-ALADIN52), while with RCP8.5, the increase is between $3.2^{\circ} \mathrm{C}$ and $5.7^{\circ} \mathrm{C}\left(4^{\circ} \mathrm{C}\right.$ in HMS-ALADIN52) by the end of the 21 st century.

Earlier studies based on SRES scenarios showed that Hungary lies in a very uncertain area in Europe concerning the future evolution of precipitation (Christensen et al., 2007b; Coppola et al., 2021), but the majority of the simulations projected summer reduction and winter increase in the Carpathian Basin. Szabó and Szépszó (2016) proved the key role of the internal variability in projection uncertainty for this region. HMS-ALADIN52 simulations suggest a definite increase exceeding $10 \%$ in all seasons with RCP4.5 scenario. The EuroCORDEX simulations project a precipitation increase in winter and spring for both future 30-year periods, and in autumn at the end of the century, however, the sign of the summer change is uncertain. Summer precipitation decrease may occur for both scenarios, but higher temperature change values are associated with those using the RCP8.5 scenario. Considering the whole century, HMS-ALADIN52 simulations are in the "upper" part of the spread (indicating higher values than the median), especially in the first part of the 21 st century, and also completes the Euro-CORDEX range in a positive direction.

The three ALADIN RCMs show similar evolution of annual temperature change, though CNRM-ALADIN63 indicates higher changes throughout the 21th century. CNRM-ALADIN63 shows lower precipitation increase compared to HMS-ALADIN52 and CNRM-ALADIN53. Moreover, and contrary to the other versions, CNRM-ALADIN63 assumes decrease in autumn with RCP4.5 in the near future, and in summer for both future periods with both scenarios (e.g., by 
the end of the century $-0.5 \%$ and $-11 \%$ relative change with RCP 4.5 and RCP8.5, respectively). CNRM-ALADIN63 shows a nearly systematic lower precipitation amounts in summer compared to HMS-ALADIN52 and CNRM-ALADIN53 (which are relatively close to each other) from the 2010s till the end of the 21st century. The differences are likely related to the changes in physical parameterizations made between ALADIN5 and ALADIN6 as a result of a 10year model development. Only further investigations implying sensitivity simulations for each parameterization may be able to reveal the specific reasons behind the simulated differences. This is far out of the scope of the current study.

Our further plans include the investigation of climate indices and extremes in HMS-ALADIN52 projections as well as in the Euro-CORDEX ensemble, and a joint evaluation of HMS-ALADIN52 and REMO2015 - also adapted at HMS results.

Acknowledgements: The research reported in this paper was supported by the KlimAdat project implemented in the framework of the Environmental and Energy Efficiency Operative Program focusing on the Water management and climate adaptation planning, information technology and monitoring development (KEHOP-1.1.0-15-2015-00001), and by the RCMGiS project (entitled: New climate scenarios based on the change in radiative forcing over the Carpathian Basin) supported by the European Economic Area Grants (EEA-C13-10). Special thanks to András Horányi (European Centre for Medium-Range Weather Forecasts) for the help and useful advices, to Antoinette Alias (Centre National de Recherches Météorologiques, CNRM) for the technical support and the guidance with ALADIN, to Péter Szabó for pre-processing the used Euro-CORDEX data, and to Andrea Király and Otília MegyeriKorotaj for their contribution where Euro-CORDEX is discussed. We acknowledge the CARPATCLIM-HU for the gridded historical dataset based on in-situ observation, and the World Climate Research Programme's Working Group on Regional Climate, and the Working Group on Coupled Modelling, former coordinating body of CORDEX and responsible panel for CMIP5. We also thank the Euro-CORDEX climate modeling groups for producing and making available their model output. We also acknowledge the Earth System Grid Federation infrastructure, an international effort led by the U.S. Department of Energy's Program for Climate Model Diagnosis and Intercomparison.

\section{References}

Bede-Fazekas, Á., Czúcz, B., and Somodi, I., 2017: Vulnerability of natural landscapes to climate change - a case study of Hungary. Időjárás 121, 392-414.

Belda, M., Skalák, P., Farda, A., Halenka, T., Déqué, M., Csima, G., Bartholy, J., Torma, Cs., Boroneant, C., Caian, M., and Valery, V., 2015: CECILIA Regional Climate Simulations for Future Climate: Analysis of Climate Change Signal. Advances in Meteorology. https://doi.org/10.1155/2015/354727

Bihari, Z., Lakatos, M., and Szentimrey, T., 2017: Felszíni megfigyelésekböl készített rácsponti adatbázisok az Országos Meteorológiai Szolgálatnál, Légkör 62, 148-151. (in Hungarian)

Bougeault, P., 1985: A simple parameterization of the large-scale effects of cumulus convection. Mon. Weather. Rev. 113, 2108-2121. https://doi.org/10.1175/1520-0493(1985)113<2108:ASPOTL >2.0.CO;2

Charnock, H., 1955: Wind stress on a water surface. Quart. J. Roy. Meteor. Soc. 81, 639-640. https://doi.org/10.1002/qj.49708135027

Christensen, O.B., Drews, M., Christensen, J.H., Dethloff, K., Ketelsen, K., Hebestadt, I., and Rinke, A., 2006: The HIRHAM regional climate model, version 5. Technical Report, Danish Meteorological Institute, Copenhagen, 6-17. 
Christensen, J.H., Carter, T.R., Rummukainen, M., and Amanatidis, G., 2007a: Evaluating the performance and utility of climate models: the PRUDENCE project. Climat. Change 81, (PRUDENCE Special Issue), 1-6. https://doi.org/10.1007/s10584-006-9211-6

Christensen, J.H., Hewitson B., Busuioc, A., Chen, A., Gao, X., Held, I., Jones, R., Kolli, R.K., Kwon, W.-T., Laprise, R., Magaña Rueda, V., Mearns, L., Menéndez, C.G., Räisänen, J., Rinke, A., Sarr, A., Whetton, P., 2007: Regional Climate Projections. In (Eds. Solomon, S., D. Qin, M. Manning, Z. Chen, M. Marquis, K.B. Averyt, M. Tignor and H.L. Miller) Climate Change 2007b: The Physical Science Basis. Contribution of Working Group I to the Fourth Assessment Report of the Intergovernmental Panel on Climate Change. Cambridge University Press, Cambridge, United Kingdom and New York, NY, USA.

Cinquini, L., Crichton, D., Mattmann, C., Harney, J., Shipman, G., Wang, F., Ananthakrishnan, R., Miller, N., Denvil, S., Morgan, M., Pobre, Z., Bell, M.G., Doutriaux, C., Drach, R., Williams, D., Kershaw, P., Pascoe, S., Gonzalez, E., Fiore, S., and Schweitzer, R., 2014: The Earth System Grid Federation: an open infrastructure for access to distributed geospatial data. Fut. Generat. Comput. Syst. 36, 400-417. https://doi.org/10.1016/j.future.2013.07.002

Colin, J., Déqué, M., Radu, R., and Somot, S., 2010: Sensitivity study of heavy precipitations in Limited Area Model climate simulation: influence of the size of the domain and the use of the spectral nudging technique. Tellus-A 62, 591-604. https://doi.org/10.1111/j.1600-0870.2010.00467.x

Coppola, E., Nogherotto, R., Ciarlo, J.M., Giorgi, F., van Meijgaard, E., Kadygrov, N., Iles, C., Corre, L., Sandstad, M., Somot, S., Nabat, P., Vautard, R., Levavasseur, G., Schwingshackl, C., Sillmann, J., Kjellström, E., Nikulin, G., Aalbers, E., Lenderink, G., Christensen, O.B., Boberg, F., Lund Sørland, S., Demory, M.-E., Bülow, K., Teichmann, C., Warrach-Sagi, K., and Wulfmeyer, V., 2021: Assessment of the European Climate Projections as Simulated by the Large EUROCORDEX Regional and Global Climate Model Ensemble. J. Geophys. Res. Atmos. 126, e2019JD032356. http://doi.org/10.1029/2019JD032356

Csima, G. and Horányi, A., 2008: Validation of the ALADIN-Climate regional climate model at the Hungarian Meteorological Service. Idöjárás 112, 155-177.

Davies, H.C., 1976: A lateral boundary formulation for multi-level prediction models. Quart. J. Roy. Meteorol. Soc. 102, 405-418. https://doi.org/10.1002/qj.49710243210

Dee, D.P., Uppala, S.M., Simmons, A.J., Berrisford, P., Poli, P., Kobayashi, S., Andrae, U., Balmaseda, M. A., Balsamo, G., Bauer, P., Bechtold, P., Beljaars, A.C.M., van de Berg, L., Bidlot, J., Bormann, N., Delsol, C., Dragani, R., Fuentes, M., Geer, A.J., Haimberger, L., Healy, S.B., Hersbach, H., Hólm, E.V., Isaksen, L., Kållberg, P., Köhler, M., Matricardi, M., McNally, A. P., Monge-Sanz, B.M., Morcrette, J.-J., Park, B.-K., Peubey, C., de Rosnay, P., Tavolato, C., Thépaut, J.-N., and Vitart, F., 2011: The ERA-Interim Reanalysis: Configuration and Performance of the Data Assimilation System. Quart. J. Roy. Meteorol. Soc. 137, 553-597. https://doi.org/10.1002/qj.828

Déqué, M., Dreveton, C., Braun, A., and Cariolle, D., 1994: The ARPEGE-IFS atmosphere model: a contribution to the French community climate modelling. Clim. Dynam. 10, 249-266. https://doi.org/10.1007/BF00208992

Driouech, F., ElRhaz, K., Moufouma-Okia, W., Arjdal, K., and Balhane, S., 2020: Assessing future changes of climate extreme events in the CORDEX-MENA region using regional climate model ALADIN-climate. Earth Syst. Environ. 4. 477-492. https://doi.org/10.1007/s41748-020-00169-3

Farda, A., Déué, M., Somot, S., Horányi, A., Spiridonov, V., and Tóth, H., 2010: Model ALADIN as regional climate model for Central and Eastern Europe. Studia Geophysica et Geodaetica 54, 313-332. https://doi.org/10.1007/s11200-010-0017-7

Fouquart, Y. and Bonnel, B., 1980: Computations of solar heating of the Earth's atmosphere: A new parameterization. Contrib. Atmos. Phys. 53, 35-62.

Giorgi, F., Jones, C., and Asrar, G., 2009: Addressing climate information needs at the regional level: the CORDEX framework. WMO Bull. 54, 175-183

Giorgi, F., Torma, Cs., Coppola, E., Ban, N., Schär, C., and Somot, S., 2016: Enhanced summer convective rainfall at Alpine high elevations in response to climate warming. Nat. Geosci. 9, 584589. https://doi.org/10.1038/ngeo2761

Halenka, T., 2007: CECILIA keeping a close eye on climate change. eStrategies, Science, Technology and Innovation Projects, British Publishers, 12. 
Hawkins, E. and Sutton, R., 2011: The potential to narrow uncertainty in projections of regional precipitation change. Clim. Dynam. 37, 407-418. https://doi.org/10.1007/s00382-010-0810-6

Homolya, E., Rotárné Szalkai, Á., and Selmeczi, P., 2017: Climate impact on drinking water protected areas. Idöjárás 121, 371-392.

Illy, T., Sábitz, J., and Szépszó, G., 2015: Az ALADIN-Climate modellkísérletek eredményeinek validációja. RCMTéR (EEA-C13-10) project report.

Ivusic, S., Güttler, I., Horvath, K., Somot, S., Guérémy, J.-F., and Alias, A., 2021: Modelling the extreme precipitation over the Dinaric Alps: evaluation of the CNRM-ALADIN regional climate model. Quart. J. Roy. Meteorol. Soc. (in rev.)

Jacob, D., Elizalde, A., Haensler, A., Hagemann, S., Kumar, P., Podzun, R., Rechid, D., Remedio, A.R., Saeed, F., Sieck, K., Teichmann, C., and Wilhelm, C., 2012: Assessing the transferability of the regional climate model REMO to different coordinated regional climate downscaling experiment (CORDEX) regions. Atmosphere 3, 181-199. https://doi.org/10.3390/atmos3010181

Jacob, D., Petersen, J., Eggert, B., Alias, A., Christensen, O.B., Bouwer, L.M., Braun, A., Colette, A., Déqué, M., Georgievski, G., Georgopoulou, E., Gobiet, A., Menut, L., Nikulin, G., Haensler, A., Hempelmann, N., Jones, C., Keuler, K., Kovats, S., Kröner, N., Kotlarski, S., Kriegsmann, A., Martin, E., van Meijgaard, E., Moseley, C., Pfeifer, S., Preuschmann, S., Radermacher, C., Radtke, K., Rechid, D., Rounsevell, M., Samuelsson, P., Somot, S., Soussana, J-F., Teichmann, C., Valentini, R., Vautard, R., Weber, B., and Yiou, P., 2014: EURO-CORDEX: new highresolution climate change projections for European impact research. Reg. Environ. Change 14, 563-578. https://doi.org/10.1007/s10113-013-0499-2

Kajner, P., Czira, T., Selmeczi, P., and Sütö A., 2017: National Adaptation Geo-information System in climate adaptation planning. Idöjárás 121, 345-370.

Kis, A., Pongrácz, R., Bartholy, J., Gocic, M., Milanovic, M., and Trajkovic, S., 2020.: Multi-scenario and multi-model ensemble of regional climate change projections for the plain areas of the Pannonian Basin. Időjárás, 124, 157-190. https://doi.org/10.28974/idojaras.2020.2.2

Kovács, A., Unger, J., and Szépszó, G., 2015: Adjustment of tourism climatological indicators for the Hungarian population in assessing exposure and vulnerability to climate change. In (eds.: Demiroğlu, O.C. et al.) Proceedings of the 4th International Conference on Climate, Tourism and Recreation CCTR2015, Istanbul Policy Center, Istanbul, Turkey, 71-76. ISBN 978-605-9178-18-1.

Krüzselyi, I., Bartholy, J., Horányi, A., Pieczka, I., Pongrácz, R., Szabó, P., Szépszó, G., and Torma, Cs., 2011: The future climate characteristics of the Carpathian Basin based on a regional climate model mini-ensemble. Adv. Sci. Res. 6, 69-73. https://doi.org/10.5194/asr-6-69-2011

Kupiainen, M., Samuelsson, P., Jones, C., Jansson, C., Willén, U., Hansson, U., Ullerstig, A., Wang, S., and Döscher, R., 2011: Rossby Centre regional atmospheric model, RCA4. Rossby Centre Newsletter.

Lepesi, N., Bede-Fazekas, Á., Czúcz, B., and Somodi, I., 2017: Adaptive capacity of climate sensitive habitats to climate change in Hungary. Időjárás 121, 415-436.

Lucas-Picher, P., Somot, S., Déqué, M., Decharme, B., and Alias A., 2013: Evaluation of the regional climate model ALADIN to simulate the climate over North America in the CORDEX framework. Clim. Dynam. 41,1117-1137. https://doi.org/10.1007/s00382-012-1613-8

Madec, G., 2008: NEMO ocean engine. Note du Pole de modélisation, Institut Pierre-Simon Laplace (IPSL), France, No 27 ISSN:1288-1619.

Maraun, D., 2016: Bias correcting climate change simulations - a critical review. Curr. Climate Change Rep. 2, 211-220. https://doi.org/10.1007/s40641-016-0050-x

Maraun, D. and Widmann, M., 2018: Statistical downscaling and bias correction for climate research, Cambridge University Press. https://doi.org/10.1017/9781107588783

Masson, V., Le Moigne, P., Martin, E., Faroux, S., Alias, A., Alkama, R., Belamari, S., Barbu, A., Boone, A., Bouyssel, F., Brousseau, P., Brun, E., Calvet, J.-C., Carrer, D., Decharme, B., Delire, C., Donier, S., Essaouini, K., Gibelin, A.-L., Giordani, H., Habets, F., Jidane, M., Kerdraon, G., Kourzeneva, E., Lafaysse, M., Lafont, S., Lebeaupin Brossier, C., Lemonsu, A., Mahfouf, J.-F., Marguinaud, P., Mokhtari, M., Morin, S., Pigeon, G., Salgado, R., Seity, Y., Taillefer, F., Tanguy, G., Tulet, P., Vincendon, B., Vionnet, V., and Voldoire, A., 2013: The SURFEXv7.2 land and ocean surface platform for coupled or offline simulation of earth surface variables and fluxes. Geosci. Model Dev. 6, 929-960. https://doi.org/10.5194/gmd-6-929-2013 
Meijgaard, E. v., Ulft, L.H. v., Lenderink, G., Roode, S.R. d., Wipfler, E.L., Boers, R., and Timmermans, R. M. A. v., 2012: Refinement and application of a regional atmospheric model for climate scenario calculations of Western Europe. Wageningen: Royal Netherlands Meteorological Institute.

Mlawer, E.J., Taubman, S.J., Brown, P.D., Iacono, M.J., and Clough, S.A., 1997: Radiative transfer for inhomogeneous atmospheres: RRTM, a validated correlated-k model for the longwave. $J$. Geophys. Res. 102D, 16663-16682. https://doi.org/10.1029/97JD00237

Moss, R.H., Edmonds, J.A., Hibbard, K.A., Manning, M.R., Rose, S.K., van Vuuren, D.P., Carter T.R., Emori, S., Kainuma, M., Kram, T., Meehl, G.A., Mitchell, J.F.B., Nakicenovic, N., Riahi, K., Smith, S.J., Stouffer, R.J., Thomson, A.M., Weyant, J.P., and Wilbanks, T.J., 2010: The next generation of scenarios for climate change research and assessment. Nature 463, 747-756. https://doi.org/10.1038/nature08823

Nabat, P., Somot, S., Cassou, C., Mallet, M., Michou, M., Bouniol, D., Decharme, B., Drugé, T., Roehrig, R., and Saint-Martin, D., 2020: Modulation of radiative aerosols effects by atmospheric circulation over the Euro-Mediterranean region. Atmos. Chem. Phys. 20, 8315-8349, https://doi.org/10.5194/acp-20-8315-2020

Nakicenovic, N., Alcamo, J., Davis, G., de Vries, B., Fenhann, J., Gaffin, S., Gregory, K., Grübler, A., Jung, T.Y., Kram, T., La Rovere, E.L., Michaelis, L., Mori, S., Morita, T., Pepper, W., Pitcher, H., Price, L., Raihi, K., Roehrl, A., Rogner, H.H., Sankovski, A., Schlesinger, M., Shukla, P., Smith, S., Swart, R., van Rooijen, S., Victor, N., and Dadi, Z., 2000: IPCC special report on emissions scenarios. Cambridge University Press, Cambridge, USA.

Noilhan, J. and Planton, S., 1989: A simple parameterization of land surface processes for meteorological models. Mon. Weather Rev. 117, 536-549. https://doi.org/10.1175/1520-0493(1989)117<0536:ASPOLS $>2.0 . C O ; 2$

Radu, R., Déqué, M., and Somot, S., 2008: Spectral nudging in a spectral regional climate model. Tellus 60A, 885-897. https://doi.org/10.1111/j.1600-0870.2008.00343.x

Ricard, J.L. and Royer, J.F., 1993: A statistical cloud scheme for use in an AGCM. Annal. Geophysicae $11,1095-1115$.

Rockel, B., Will, A., and Hense, A. (eds.), 2008: Special issue Regional climate modelling with COSMOCLM (CCLM). Met. Zeitsch. 17. https://doi.org/10.1127/0941-2948/2008/0309

Salas y Melia, D., 2002: A global coupled sea ice-ocean model. Ocean Model. 42. 137-172. https://doi.org/10.1016/S1463-5003(01)00015-4

Skamarock, W.C., Klemp, J.B., Dudhia, J., Gill, D.O., Duda, D.M.B.M.G., Huang, X.Y., Wang, W., and Powers, J.G., 2008: A description of the advanced research WRF version 3. NCAR Tech. Note 475.

Smith, R.N.B., 1990: A scheme for predicting layer clouds and their water content in a general circulation model. Quart. J. Roy. Meteorol. Soc. 116, 435-460. https://doi.org/10.1002/qj.49711649210

Szabó, P. and Szépszó, G., 2016: Quantifying Sources of Uncertainty in Temperature and Precipitation Projections over Different Parts of Europe. In: (eds.: Bátkai, A., Csomós, P., Faragó, I., Horányi, A., Szépszó, G.) Mathematical Problems in Meteorological Modelling, 239-261. https://doi.org/10.1007/978-3-319-40157-7_12

Szentimrey, T., 2008: Development of MASH homogenization procedure for daily data. In: Proceedings of the Fifth Seminar for Homogenization and Quality Control in Climatological Databases, Budapest, Hungary, 2006. WCDMP-No.71, WMO/TD-No. 1493, 123-130.

Szentimrey, T., 2014: Manual of homogenization software MASHv3.03, Hungarian Meteorological Service.

Szentimrey, T. and Bihari, Z., 2007: Mathematical background of the spatial interpolation methods and the software MISH (Meteorological Interpolation based on Surface Homogenized Data Basis). In: Proceedings from the Conference on Spatial Interpolation in Climatology and Meteorology, Budapest, Hungary, 2004, COST Action 719, COST Office, 17-27.

Szentimrey, T. and Bihari, Z., 2014: Manual of interpolation software MISHv1.03. Hungarian Meteorological Service.

Szépszó, G. and Horányi, A., 2008: Transient simulation of the REMO regional climate model and its evaluation over Hungary. Időjárás 112, 203-231. 
Szopa, S., Balkanski, Y., Schulz, M., Bekki, S., Cugnet, D., Fortems-Cheiney, A., Turquety, S., Cozic, A., Déandreis, C., Hauglustaine, D., Idelkadi, A., Lathière, J., Lefevre, F., Marchand, M., Vuolo, R., Yan, N., and Dufresne, J.-L., 2013: Aerosol and ozone changes as forcing for climate evolution between 1850 and 2100. Clim. Dynam. 40, 2223-2250. https://doi.org/10.1007/s00382-012-1408-y

Taylor, K., Stouffer, R.J., Meehl, G.A., 2012: An overview of CMIP5 and the experiment design. Bull. Amer. Meteorol. Soc. 93, 485-498. https://doi.org/10.1175/BAMS-D-11-00094.1

Tegen, I., Hollrig, P., Chin, M., Fung, I., Jacob, D., and Penner, J., 1997: Contribution of different aerosol species to the global aerosol extinction optical thickness: Estimates from model results, J. Geophys. Res., 102, 23895-23915. https://doi.org/10.1029/97JD01864

Termonia, P., Fischer, C., Bazile, E., Bouyssel, F., Brožková, R., Bénard, P., Bochenek, B., Degrauwe, D., Derková, M., El Khatib, R., Hamdi, R., Mašek, J., Pottier, P., Pristov, N., Seity, Y., Smolíková, P., Španiel, O., Tudor, M., Wang, Y., Wittmann, C., and Joly, A., 2018: The ALADIN System and its canonical model configurations AROME CY41T1 and ALARO CY40T1. Geosci. Model Dev. 11, 257-281. https://doi.org/10.5194/gmd-11-257-2018

Torma, Cs., Bartholy, J., Pongrácz, R., Barcza, Z., Coppola, E., and Giorgi, F., 2008: Adaptation and validation of the RegCM3 climate model for the Carpathian Basin. Idójárás 112, 233-247.

Tramblay, Y., Ruelland, D., Somot, S., Bouaicha, R., and Servat, E., 2013: High-resolution MedCORDEX regional climate model simulations for hydrological impact studies: a first evaluation of the ALADIN-Climate model in Morocco. Hydrol. Earth Syst. Sci., 17, 3721-3739. https://doi.org/10.5194/hess-17-3721-2013

Uppala, S.M., KAllberg, P.W., Simmons, A.J., Andrae, U., Bechtold, V.D.C., Fiorino, M., Gibson, J.K., Haseler, J., Hernandez, A., Kelly, G.A., Li, X., Onogi, K., Saarinen, S., Sokka, N., Allan, R.P., Andersson, E., Arpe, K., Balmaseda, M.A., Beljaars, A.C.M., Berg, L.V.D., Bidlot, J., Bormann, N., Caires, S., Chevallier, F., Dethof, A., Dragosavac, M., Fisher, M., Fuentes, M., Hagemann, S., Hólm, E., Hoskins, B.J., Isaksen, L., Janssen, P.A.E.M., Jenne, R., Mcnally, A.P., Mahfouf, J.F., Morcrette, J.-J., Rayner, N.A., Saunders, R.W., Simon, P., Sterl, A., Trenberth, K.E., Untch, A., Vasiljevic, D., Viterbo, P., and Woollen, J., 2005: The ERA-40 re-analysis. Quart. J. Roy. Meteorol. Soc., 131, 2961-3012. https://doi.org/10.1256/qj.04.176

Valcke, S., 2006: OASIS3 user guide (prism_2-5). Technical report TR/CMGC/06/73, CERFACS, Toulouse, France.

Vautard, R., Kadygrov, N., Iles, C., Boberg, F., Buonomo, E., Bülow, K., Coppola, E., Corre, L., van Meijgaard, E., Nogherotto, R., Sandstad, M., Schwingshackl, C., Somot, S., Aalbers, E., Christensen, O.B., Ciarlo, J.M., Demory, M.-E., Giorgi, F., Jacob, D., Jones, R.G., Keuler, K., Kjellström, E., Lenderink, G., Levavasseur, G., Nikulin, G., Sillmann, J., Solidoro, C., Lund Sørland, S., Steger, C., Teichmann, C., Warrach-Sagi, K., and Wulfmeyer, V., 2021: Evaluation of the large EURO-CORDEX regional climate model ensemble. J. Geophys. Res. - Atmospheres 126, e2019JD032344. https://doi.org/10.1029/2019JD032344

Voldoire, A., Sanchez-Gomez, E., Salas y Mélia, D., Decharme, B., Cassou, C., Sénési, S., Valcke, S., Beau, I., Alias, A., Chevallier, M., Déqué, M., Deshayes, J., Douville, H., Fernandez, E., Madec, G., Maisonnave, E., Moine, M.-P., Planton, S., Saint-Martin, D., Szopa, S., Tyteca, S., Alkama, R., Belamari, S., Braun, A., Coquart, L., and Chauvin, F., 2013: The CNRM-CM5.1 Global Climate Model: Description and Basic Evaluation. Clim. Dyn. 40, 2091-2121. https://doi.org/10.1007/s00382-011-1259-y

Williamson, D.F., Parker, R.A., and Kendrick, J.S., 1989: The boxplot: a simple visual method to interpret data. Ann. Int. Medicine 110, 916-921. https://doi.org/10.7326/0003-4819-110-11-916 